Prepared in cooperation with the Federal Emergency Management Agency and the Minnesota Department of Natural Resources, Division of Ecological and Water Resources

\title{
Floods of September 2010 in Southern Minnesota
}

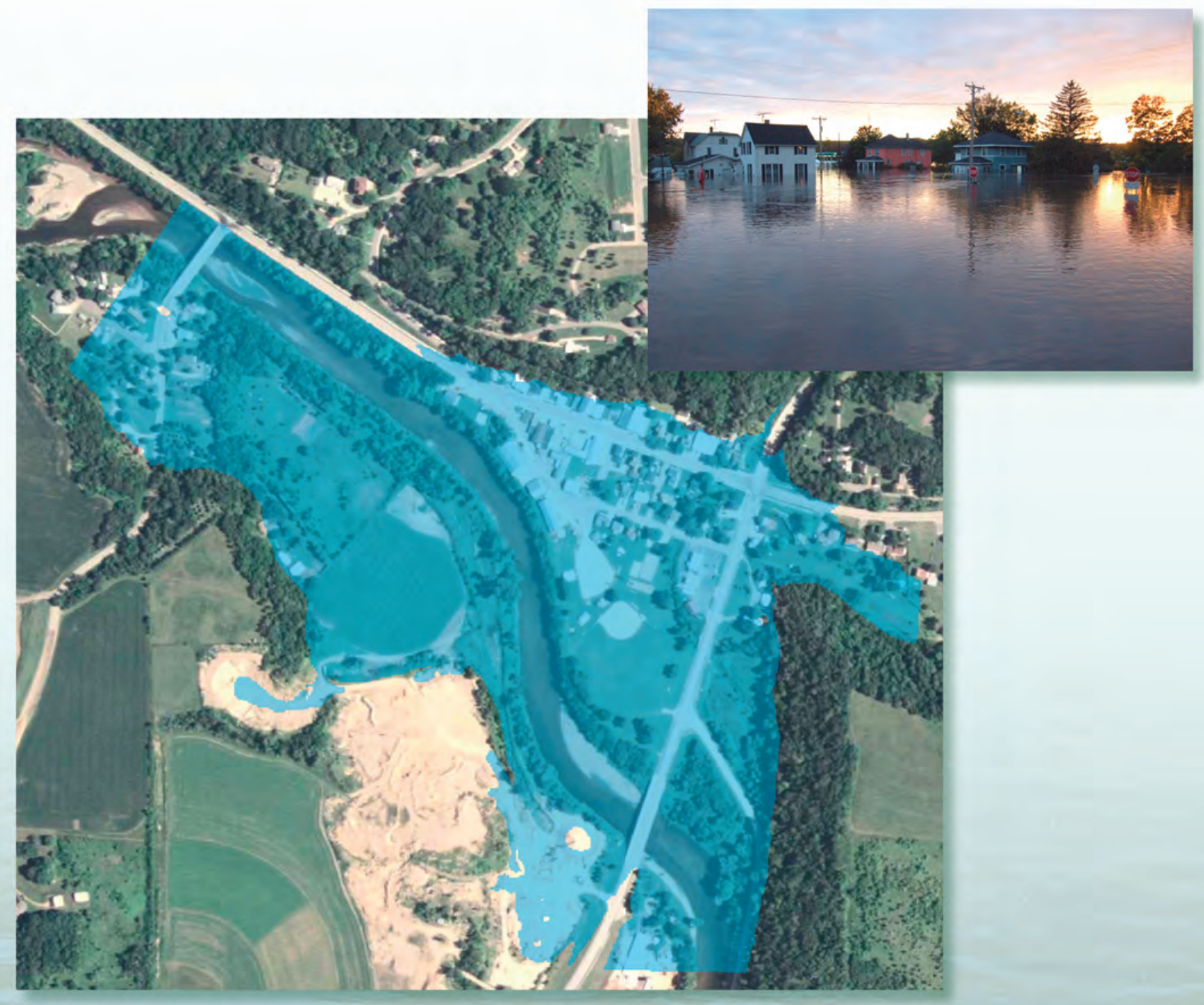

Scientific Investigations Report 2011-5045 
Cover. Left: Flood-inundation map prepared by Chris Sanocki, U.S. Geological Survey, January 2011. Map base from 2009 National Agricultural Imagery program (U.S. Department of Agriculture, 2009).

Right: View of the Zumbro River near the intersection of State Route 60 and U.S. Route 63 at Zumbro Falls, Minn., September 25, 2010. (Photograph by Bill Holmes, resident of the community of Zumbro Falls). 


\section{Floods of September 2010 in Southern Minnesota}

By Christopher A. Ellison, Chris A. Sanocki, David L. Lorenz, Gregory B. Mitton, and Gregory A. Kruse

Prepared in cooperation with the Federal Emergency Management Agency and the Minnesota Department of Natural Resources, Division of Ecological and Water Resources

Scientific Investigations Report 2011-5045 


\section{U.S. Department of the Interior \\ KEN SALAZAR, Secretary \\ U.S. Geological Survey \\ Marcia K. McNutt, Director}

\section{U.S. Geological Survey, Reston, Virginia: 2011}

For more information on the USGS — the Federal source for science about the Earth, its natural and living resources, natural hazards, and the environment, visit http://www.usgs.gov or call 1-888-ASK-USGS.

For an overview of USGS information products, including maps, imagery, and publications, visit http://www.usgs.gov/pubprod

Any use of trade, product, or firm names is for descriptive purposes only and does not imply endorsement by the U.S. Government.

Although this report is in the public domain, permission must be secured from the individual copyright owners to reproduce any copyrighted materials contained within this report.

Suggested citation:

Ellison, C.A., Sanocki, C.A., Lorenz, D.L., Mitton, G.B., and Kruse, G.A., 2011, Floods of September 2010 in Southern Minnesota: U.S. Geological Survey Scientific Investigations Report 2011-5045, 37 p., 3 app. 


\section{Acknowledgments}

This report presents a compilation of information supplied by many agencies and individuals. The authors would like to thank the Minnesota Department of Natural Resources, Division of Ecological and Water Resources; Doug Neville and Bruce Gordon from the Minnesota Department of Public Safety; and the Minnesota Silver Jackets Hazard Mitigation Taskforce for their assistance with this study. Abraham Algadi, City Administrator of the community of Pine Island, provided damage assessment information, photographs, and aerial video, and helped in defining areas of inundation along the North Branch and the Middle Fork Zumbro River.

Faith Fitzpatrick, Marie Peppler, and James Fallon of the U.S. Geological Survey are acknowledged for their technical reviews of the report. Erich Kessler, Josh Ayers, Jennifer Bode, Molly Trombly, Richard Liggett, Doug VerDouw, and Bill Damschen of the U.S. Geological Survey are acknowledged for assistance with office and field aspects of the study. 


\section{Contents}

Acknowledgments ......................................................................................................................

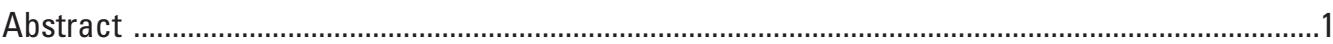

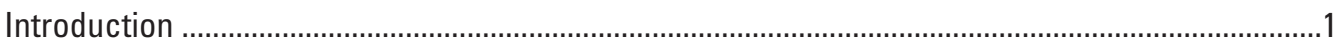

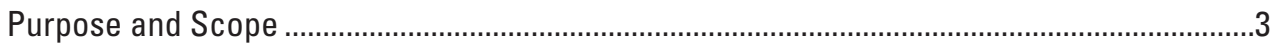

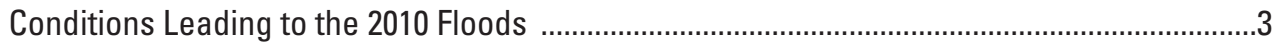

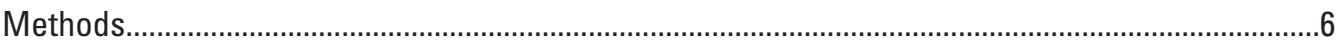

Computing the Magnitudes of Peak Streamflows ....................................................................

Estimating Annual Exceedance Probabilities of Peak Streamflows ..........................................

Collection of High-Water-Mark Data .....................................................................................

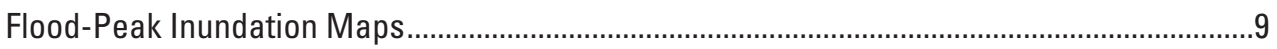

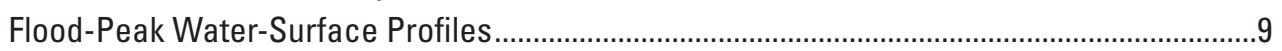

Floods of September 2010 in Southern Minnesota .........................................................................

Magnitudes and Estimated Annual Exceedance Probabilities of Peak Streamflows...............9

Flood-Peak Inundation Maps and Water-Surface Profiles ....................................................15

Description of Flood Damages and Effects ...............................................................................16

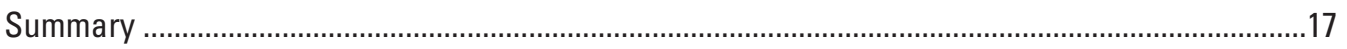

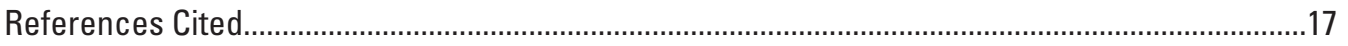

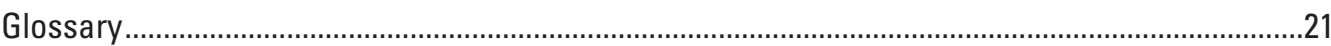

Appendix 1. High-Water-Mark Descriptions in the Communities of Faribault, Owatonna, Pine Island, and Zumbro Falls, Floods of September 2010, Minnesota

Appendix 2. Flood-Peak Inundation Maps for Selected Communities, Floods of

September 2010, Minnesota ............................................................................................25

Appendix 3. Flood-Peak Water-Surface Profiles for Selected Sites, Floods of

September 2010, Minnesota...........................................................................................

\section{Figures}

1. Map showing 21 counties were declared disaster areas because of severe storms and flooding during the period of September 22 through

September 25, 2010.

2. Map showing distribution of rainfall totals September 22-24, 2010, and rainfall totals for the National Weather Service stations.

3. Graph showing cumulative daily rainfall for selected National Weather Service precipitation stations during September 20-26, 2010, in southern Minnesota

4. Map showing locations of selected U.S. Geological Survey and Minnesota Department of Natural Resources streamgages and ungaged sites

5. Hydrographs showing selected U.S. Geological Survey streamgages in southern Minnesota for September through October 2010. 


\section{Appendix 2}

2-1. Map showing approximate flood-peak extents and heights, flood of September 2010, for Cannon River and Straight River at Faribault, Minnesota...............26

2-2. Map showing approximate flood-peak extents and heights, flood of September 2010, for Straight River and Maple Creek at Owatonna, Minnesota .............28

2-3. Map showing approximate flood-peak extents and heights, flood of September 2010, North Branch and Middle Fork Zumbro River near Pine Island, Minnesota

2-4. Map showing approximate flood-peak extents and heights, flood of September 2010, for Zumbro River at Zumbro Falls, Minnesota

\section{Appendix 3}

3-1. Graph showing flood-peak water-surface profile with selected high-water marks for the Cannon River at Faribault, Minnesota, for flood of September 2010

3-2. Graph showing flood-peak water-surface profile with selected high-water marks for the Straight River at Faribault, Minnesota, for flood of September 2010

3-3. Graph showing flood-peak water-surface profile with selected high-water marks for Straight River at Owatonna, Minnesota, for flood of September 2010

3-4. Graph showing flood-peak water-surface profile with selected high-water marks for Maple Creek at Owatonna, Minnesota, for flood of September 2010

3-5. Graph showing flood-peak water-surface profile with selected high-water marks for the North Branch at Pine Island, Minnesota, for flood of September 2010

3-6. Graph showing flood-peak water-surface profile with selected high-water marks for the Middle Fork Zumbro River at Pine Island, Minnesota, for flood of September 2010

3-7. Graph showing flood-peak water-surface profile with selected high-water marks for the Zumbro River at Zumbro Falls, Minnesota, for flood of September 2010 .

\section{Tables}

1. Total rainfall for September 22-24, 2010, and 72-hour duration rainfalls for selected annual exceedance probabilities at selected National Weather Service precipitation stations in Minnesota

2. Flood-peak gage heights, peak streamflows, and annual exceedance probabilities of peak streamflows during the floods of September 2010 at selected U.S. Geological Survey and Minnesota Department of Natural Resources streamgages in Minnesota

3. Peak streamflows and estimated annual exceedance probabilities during the floods of September 2010, at selected ungaged locations in Minnesota 


\section{Appendix 1}

1-1. High-water-mark descriptions in the communities of Faribault, Owatonna,

Pine Island, and Zumbro Falls, floods of September 2010, Minnesota

\section{Conversion Factors and Datums}

\begin{tabular}{lcl}
\hline & Multiply & \multicolumn{1}{c}{ Bo obtain } \\
\hline inch (in.) & Length & \\
inch (in.) & 2.54 & centimeter $(\mathrm{cm})$ \\
foot (ft) & 25.4 & millimeter $(\mathrm{mm})$ \\
mile (mi) & 0.3048 & meter $(\mathrm{m})$ \\
& 1.609 & kilometer $(\mathrm{km})$ \\
\hline square mile $\left(\mathrm{mi}^{2}\right)$ & Area & \\
\hline & 2.590 & square kilometer $\left(\mathrm{km}^{2}\right)$ \\
\hline cubic foot $\left(\mathrm{ft}^{3}\right)$ & Volume & cubic meter $\left(\mathrm{m}^{3}\right)$ \\
\hline & 0.02832 & \\
\hline cubic foot per second $\left(\mathrm{ft}^{3} / \mathrm{s}\right)$ & Flow rate & cubic meter per second $\left(\mathrm{m}^{3} / \mathrm{s}\right)$ \\
inch per hour $(\mathrm{in} / \mathrm{h})$ & 0.02832 & meter per hour $(\mathrm{m} / \mathrm{h})$ \\
\hline
\end{tabular}

Vertical coordinate information is referenced to the North American Vertical Datum of 1988 (NAVD 88) or the National Geodetic Vertical Datum of 1929 (NGVD 29).

Horizontal coordinate information is referenced to the North American Datum of 1983 (NAD 83).

Elevation, as used in this report, refers to distance above the vertical datum.

Water year is the 12-month period of October 1 through September 30 designated by the calendar year in which it ends.

\section{Abbreviations and Acronyms}

$\begin{array}{ll}\text { DEM } & \text { digital elevation model } \\ \text { FEMA } & \text { Federal Emergency Management Agency } \\ \text { GIS } & \text { geographic information system } \\ \text { HAZUS-MH } & \text { Hazards U.S. Multi-Hazards } \\ \text { HEC-RAS } & \text { Hydrologic Engineering Center River Analysis System } \\ \text { LiDAR } & \text { Light detection and ranging } \\ \text { MDNR } & \text { Minnesota Department of Natural Resources } \\ \text { MDPS } & \text { Minnesota Department of Public Safety } \\ \text { MHSEM } & \text { Minnesota Homeland Security and Emergency Management } \\ \text { NOAA } & \text { National Oceanic and Atmospheric Administration } \\ \text { NWS } & \text { National Weather Service } \\ \text { RTK-GPS } & \text { Real-Time Kinematic Global Positioning System } \\ \text { TIN } & \text { triangular irregular network } \\ \text { USGS } & \text { U.S. Geological Survey }\end{array}$




\title{
Floods of September 2010 in Southern Minnesota
}

\author{
By Christopher A. Ellison', Chris A. Sanocki', David L. Lorenz', Gregory B. Mitton', and Gregory A. Kruse ${ }^{2}$
}

\section{Abstract}

During September 22-24, 2010, heavy rainfall ranging from 3 inches to more than 10 inches caused severe flooding across southern Minnesota. The floods were exacerbated by wet antecedent conditions, where summer rainfall totals were as high as 20 inches, exceeding the historical average by more than 4 inches. Widespread flooding that occurred as a result of the heavy rainfall caused evacuations of hundreds of residents, and damages in excess of 64 million dollars to residences, businesses, and infrastructure. In all, 21 counties in southern Minnesota were declared Federal disaster areas.

Peak-of-record streamflows were recorded at nine U.S. Geological Survey and three Minnesota Department of Natural Resources streamgages as a result of the heavy rainfall. Flood-peak gage heights, peak streamflows, and annual exceedance probabilities were tabulated for 27 U.S. Geological Survey and 5 Minnesota Department of Natural Resources streamgages and 5 ungaged sites. Flood-peak streamflows in 2010 had annual exceedance probabilities estimated to be less than 0.2 percent (recurrence interval greater than 500 years) at 7 streamgages and less than 1 percent (recurrence interval greater than 100 years) at 5 streamgages and 4 ungaged sites. High-water marks were identified and tabulated for the most severely affected communities of Faribault along the Cannon and Straight Rivers, Owatonna along the Straight River and Maple Creek, Pine Island along the North Branch and Middle Fork Zumbro River, and Zumbro Falls along the Zumbro River. The nearby communities of Hammond, Henderson, Millville, Oronoco, Pipestone, and Rapidan also received extensive flooding and damage but were not surveyed for high-water marks. Flood-peak inundation maps and watersurface profiles for the four most severely affected communities were constructed in a geographic information system by combining high-water-mark data with the highest resolution digital elevation model data available. The flood maps and profiles show the extent and height of flooding through the communities and can be used for flood response and recovery efforts by local, county, State, and Federal agencies.

\section{Introduction}

Flood data are needed by Federal, State, and local agencies to make informed decisions in meeting mission requirements related to flood hazard mitigation, planning, and response. For example, the Federal Emergency Management Agency (FEMA), Minnesota Department of Natural Resources (MDNR), Minnesota Department of Public Safety (MDPS), and Minnesota Homeland Security and Emergency Management (MHSEM) need timely information on the magnitudes and frequency of floods to help respond to flood damage, enhance emergency response management, protect infrastructure, provide recovery guidance from the National Flood Insurance Program and State regulatory programs, and plan for future flood events.

Heavy rains caused severe flooding during September 2010 in parts of southern Minnesota (National Oceanic and Atmospheric Administration, 2010a), and prompted the National Weather Service (NWS) to issue flash-flood warnings, areal flood warnings, and river flood warnings. The flood peaks were exacerbated by an exceptionally wet summer as a result of a wet June and heavy downpours in August. Summer rainfall totals as high as 20 inches (in.) were reported in southern Minnesota, exceeding the historical average by more than 4 in. (Minnesota Department of Natural Resources State Climatology Office, 2010a). During September 22 through 25, evacuations, water rescues, and road closures were common in communities affected by the flooding. In Goodhue, Rice, Steele, and Wabasha Counties, damages from flooding were extensive and included major transportation disruptions and damage to hundreds of homes and businesses, dams and floodcontrol structures, agricultural crops, and critical facilities including utilities (Minnesota State Emergency Operations Center, 2010). On October 1, 2010, Minnesota Governor Tim Pawlenty requested a major disaster declaration because of the severe storms and flooding. Damage caused by the flooding resulted in a Presidential Disaster Declaration on October 13, 2010, for 21 southern Minnesota counties (Federal Emergency Management Agency, 2010a; fig. 1).

\footnotetext{
${ }^{1}$ U.S. Geological Survey.

${ }^{2}$ Minnesota Department of Natural Resources.
} 


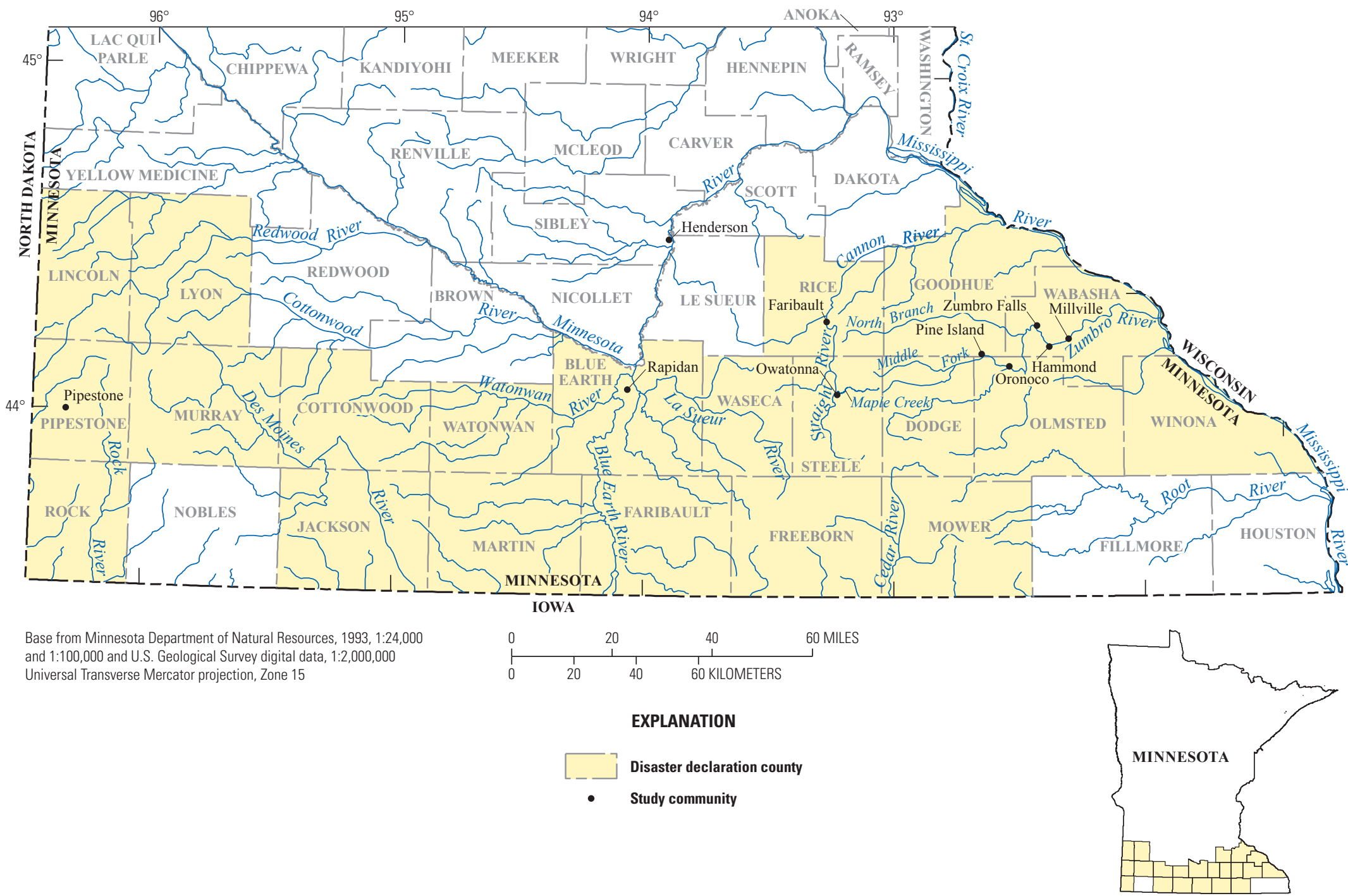

Figure 1. Twenty-one counties were declared disaster areas because of severe storms and flooding during the period of September 22 through September 25 , 2010 (Federal Emergency Management Agency, 2010a). 
Given the severity of the September 2010 flooding in Minnesota, the U.S. Geological Survey (USGS), in cooperation with FEMA and MDNR, Division of Ecological and Water Resources, conducted a study to:

- Document the meteorological and hydrological conditions leading to the flood;

- Compile flood-peak gage heights, ${ }^{3}$ streamflows, and annual exceedance probabilities at USGS and MDNR streamgages; and

- Compute streamflows and annual exceedance probabilities at selected ungaged locations.

The study also provided data to construct flood profiles and flood-peak inundation maps. Flood profiles and flood-peak inundation maps were constructed for four communities along six streams in southern Minnesota: Faribault along the Cannon and Straight Rivers; Owatonna along the Straight River and Maple Creek; Pine Island along the North Branch and Middle Fork Zumbro River; and Zumbro Falls along the Zumbro River.

\section{Purpose and Scope}

The purpose of this report is to provide meteorological and hydrologic information pertaining to the floods of September 2010 in southern Minnesota. The report summarizes meteorological and hydrologic conditions leading up to the flood. The report contains computed flood-peak magnitudes and annual exceedance probabilities for 27 USGS and 5 MDNR streamgages and 5 ungaged sites, except where otherwise noted. Data for high-water marks and flood-peak inundation maps and profiles are presented and described for four communities along six streams. Peak streamflows were calculated using a stage-to-discharge rating curve at most streamgages. At selected sites, peak streamflows were computed by using indirect methods. Flood damages and effects are summarized on the basis of information obtained from FEMA, NWS, MDPS, MHSEM, MDNR, local agencies, news accounts, photographs, and corroborated testimony from individuals in affected communities.

\section{Conditions Leading to the 2010 Floods}

The September 2010 flooding in southern Minnesota was caused by heavy rainfall on areas that had already received above-normal precipitation. An exceptionally wet summer preceded the September flooding. Large seasonal rainfall totals were primarily the result of a wet June and heavy downpours in August. Summer rainfall totals as high as 20 in. were reported in southern Minnesota, exceeding the historical average by more than 4 in. (Minnesota Department of Natural Resources State Climatology Office, 2010a). Preliminary analysis of rainfall totals indicated that September was the wettest September in Minnesota's modern climate record that extends back to 1891 (Minnesota Department of Natural Resources State Climatology Office, 2010b). The largest contribution to the new state-wide record came from southern Minnesota where monthly totals as high as $10 \mathrm{in}$. were common. During September 22-24, heavy rain developed over southern Minnesota, helped in part by deep tropical-origin moisture from former tropical cyclones (National Oceanic and Atmospheric Administration, 2010a). Moisture from the remnants of tropical storm Georgette in the eastern Pacific Ocean and Hurricane Karl in the Gulf of Mexico moved northward into the region and enhanced rainfall rates over southern Minnesota. This moisture, along with instability, was brought northward by low pressure in the central Plains. The first low pressure on September 22 developed in Kansas and moved into northwest Iowa, uplifting the first surge of moist and unstable air across the area. Widespread heavy-rain producing storms developed and moved steadily from west to east over southern Minnesota, in an axis north of the surface warm front (National Oceanic and Atmospheric Administration, 2010a). A second low pressure system lifted northward into Minnesota on September 23, providing an even larger tropical moisture surge, which resulted in sustained heavy rainfall in southern Minnesota. The City of Amboy in Blue Earth County received 10.68 in. of rain between September 22 and 24, and Zumbro Falls in Wabasha County received 8.50 in. of rain in the same period (Minnesota Department of Natural Resources State Climatology Office, 2010c; fig. 2).

A map of estimated rainfall totals prepared from National Oceanic and Atmospheric Administration (NOAA)/NSSL NMQ/Q2 system (National Oceanic and Atmospheric Administration, 2010b) shows rainfall totals ranging from 3 in. to more than 10 in. for September 22-24 across southern Minnesota (fig. 2). Total rainfall amounts for six NWS precipitation stations from September 22-24 ranged from 5.75 in. at Pipestone in Pipestone County to 10.68 in. at Amboy in Blue Earth County (table 1). The 100-year (annual exceedance probability of 0.01 , or 1 percent) 72-hour rainfall for southern Minnesota is about $7 \mathrm{in}$. (Huff and Angel, 1992). Rainfall at precipitation stations for Amboy in Blue Earth County, Owatonna in Steele County, Winnebago in Faribault County, Zumbro Falls in Wabasha County, and Zumbrota in Goodhue County exceeded the 100-year 72-hour rainfall amount for southern Minnesota (table 1). A graph of daily cumulative rainfall (fig. 3) at selected NWS precipitation stations illustrates the rainfall patterns. Distribution of rainfall amounts (fig. 2) and rainfall patterns (fig. 3) show that the most severely affected communities were located along a defined line of heavy rainfall through southern Minnesota.

\footnotetext{
${ }^{3}$ Terms in bold type are defined in the Glossary at the back of the report.
} 


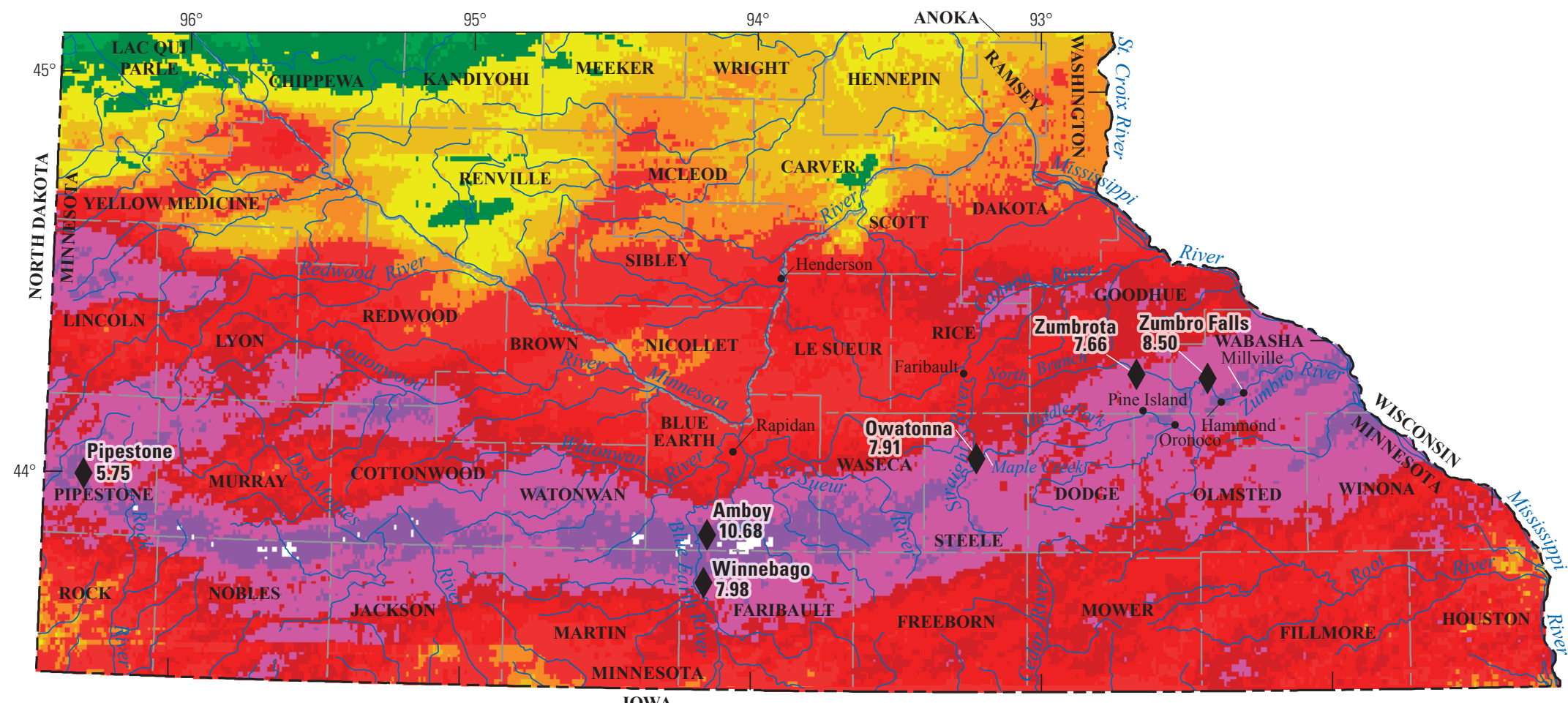

Base from Minnesota Department of Natural Resources, 1993, 1:24,000 and 1:100,000 and U.S. Geological Survey digital data, 1:2,000,000 Universal Transverse Mercator projection, Zone 15

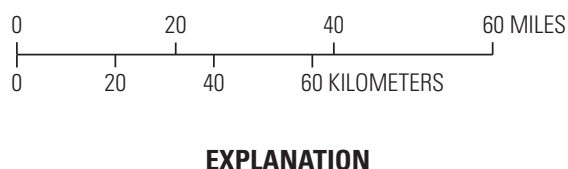

EXPLANATION

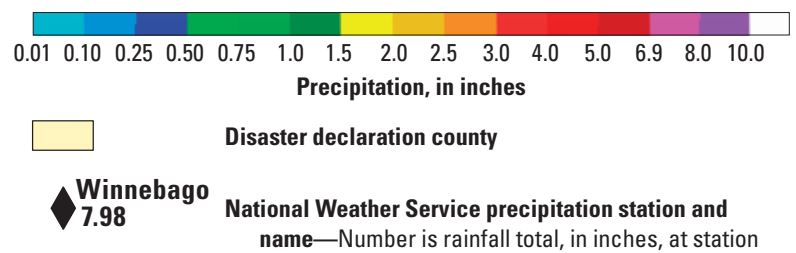

Figure 2. Distribution of rainfall totals September 22-24, 2010, and rainfall totals for the National Weather Service stations. 
Table 1. Total rainfall for September 22-24, 2010, and 72-hour duration rainfalls for selected annual exceedance probabilities at selected National Weather Service (NWS) precipitation stations in Minnesota.

[Total rainfall from Minnesota Department of Natural Resources State Climate Office (2010c). Annual exceedance probabilities from Huff and Angel (1992). NWS, National Weather Service]

\begin{tabular}{|c|c|c|c|c|c|c|c|c|}
\hline \multirow{2}{*}{$\begin{array}{c}\text { Station name } \\
\text { (location shown } \\
\text { in fig. 2) }\end{array}$} & \multirow[t]{2}{*}{ County } & \multirow{2}{*}{$\begin{array}{c}\text { NWS } \\
\text { station } \\
\text { identifier }\end{array}$} & \multirow{2}{*}{$\begin{array}{l}\text { Total rainfall } \\
\text { (inches) }\end{array}$} & \multicolumn{5}{|c|}{$\begin{array}{l}\text { 72-hour duration rainfall (inches) for selected annual } \\
\text { exceedance probabilities }{ }^{1}\end{array}$} \\
\hline & & & & 0.20 & 0.10 & 0.04 & 0.02 & 0.01 \\
\hline Owatonna, Minn. & Steele & 216287 & 7.91 & 4.06 & 4.77 & 5.67 & 6.43 & 7.08 \\
\hline Pipestone, Minn. & Pipestone & 216565 & 5.75 & 3.96 & 4.57 & 5.50 & 5.93 & 7.13 \\
\hline Zumbrota, Minn. & Goodhue & 219249 & 7.66 & 4.35 & 4.97 & 5.74 & 6.30 & 6.83 \\
\hline
\end{tabular}

${ }^{1}$ The annual exceedance probability is the probability that a given event will be exceeded or equaled in any given year. For example, the annual exceedance probability of the 100 -year rainfall is 0.01 . In other words, there is a 1 -percent chance that the rainfall would be exceeded or equaled in any given year.

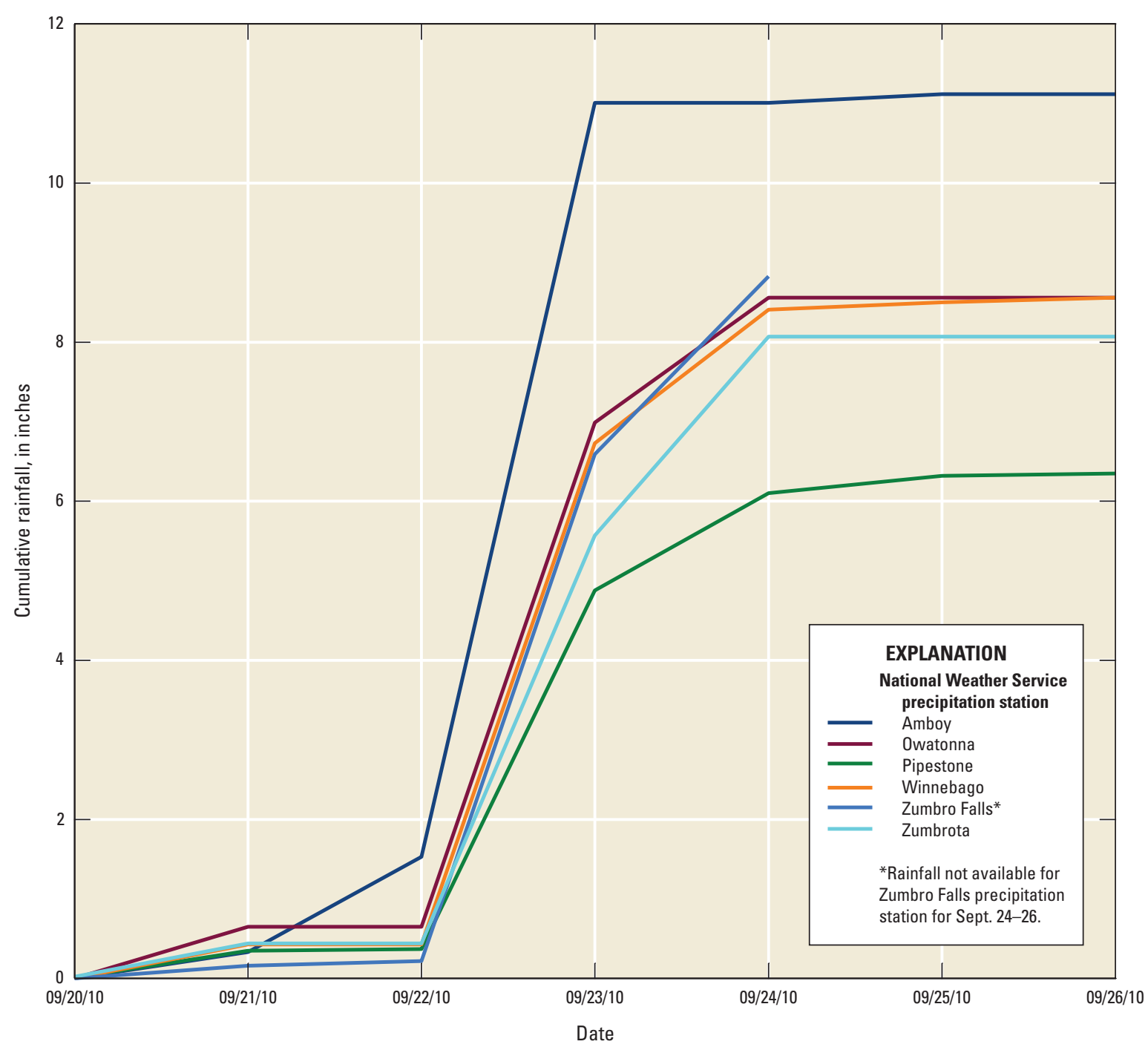

Figure 3. Cumulative daily rainfall for selected National Weather Service precipitation stations during September 20-26, 2010, in southern Minnesota. 


\section{Methods}

The methods used to compute magnitudes and annual exceedance probabilities of peak streamflows and to collect high-water-mark data are described in this section of the report. Methods used to create flood-peak inundation maps and water-surface profiles also are described.

\section{Computing the Magnitudes of Peak Streamflows}

Peak streamflows documented in this study were determined at 27 USGS and 5 MDNR streamgages (fig. 4) by use of a stage-to-discharge rating curve (or rating curve, the relation between streamgage height and streamflow) unique to each streamgage. Stage-discharge relations at streamgages are developed by relating paired measurements of stage (gage height) and streamflow over the range of streamflows that occur. Paired measurements used to develop a rating are determined most commonly by direct measurement of stage (observed/recorded) and streamflow (velocity meter) at the streamgage (Rantz and others, 1982); or, if direct measurement is not possible, by indirect hydraulic methods (Benson and Dalrymple, 1967). The rating curve is developed using available stage/streamflow measurements and controlling hydraulic features of the channel. The rating curve can be extrapolated slightly beyond the highest measurement of stage/streamflow, depending on available information about channel geometry and hydraulic conditions.

Flood-peak gage heights were obtained either from electronic data recorders or from surveyed high-water marks near streamgages (where recorders or stage sensors malfunctioned or if streamgages were not available). For example, at the Zumbro River at Zumbro Falls, the USGS streamgage failed to record the flood-peak gage height after becoming inundated with water, so high-water marks near the streamgage were surveyed. The stage-discharge relation at each streamgage was used to compute peak streamflow from the flood-peak gage height. Direct or indirect streamflow measurements served as flood-event data points for rating-curve verification and extrapolation.

In cases where no nearby streamgages were available or if the equipment was damaged during a flood at a streamgage, one of three methods was used to compute peak streamflow: (1) the slope-area method, (2) the drainage-area ratio method, or (3) use of the Hydrologic Engineering Center River Analysis System (HEC-RAS) water-surface profile model (U.S. Army Corps of Engineers, 2010). For the Zumbro River at Zumbro Falls (USGS streamgage 05374000), where equipment was damaged, the slope-area method (Dalrymple and Benson, 1968) was used to measure peak streamflow. For Turtle Creek (USGS/MDNR streamgage 05352810/39054001), near the community of Owatonna, streamflow was computed by extrapolating the stage-discharge rating curve and using the slope-area method to compute the additional streamflow that had flooded over the roadway. In the slope-area method, streamflow is computed on the basis of a uniform-flow equation involving channel characteristics, water-surface profiles, and a roughness coefficient (Rantz and others, 1982). Computations were done with the USGS slope-area computation program (Fulford, 1995) and surveyed channel geometry and high-water-mark data.

Peak streamflow was estimated for the community of Faribault using the drainage-area ratio method (Ries, 2007). In addition to Faribault, peak streamflows for the communities of Oronoco, Hammond, and Millville also were estimated using this method. In the drainage-area ratio method, the streamflow of the ungaged site is estimated using streamflow from a streamgage or from streamflow that was measured upstream or downstream from the ungaged site and from the ratio between the drainage area of the ungaged site and the drainage area of the gaged site. Normally, the method is applied only if the drainage area ratio is between 0.5 and 1.5 (Ries, 2007), but the ratios can be set differently for each State if information is available to support changing them. The equation used to determine the drainage-area ratio estimates, modified from Ries (2007), is:

$$
Q_{u}=\left(A_{u} / A_{g}\right)^{b} \times Q_{g}
$$

where

$$
\begin{aligned}
& Q_{u} \quad \begin{array}{l}
\text { is the estimated flow statistic for the ungaged } \\
\text { site in cubic feet per second, }
\end{array} \\
& A_{u} \quad \text { is the drainage area for the ungaged site in } \\
& \text { square miles, } \\
& A_{g} \quad \text { is the drainage area for the upstream or } \\
& \text { downstream streamgage (or site upstream } \\
& \text { or downstream where streamflow was } \\
& \text { measured) in square miles, } \\
& Q_{g} \quad \text { is the streamflow for the streamgage (or site } \\
& \text { upstream or downstream where streamflow } \\
& \text { was measured) in cubic feet per second, } \\
& \text { and } \\
& \text { is the exponent of drainage area from the } \\
& \text { appropriate regression equation, or } 1 \text { where } \\
& \text { not defined. }
\end{aligned}
$$

A general description of the slope-area method can be found in Rantz and others (1982), and the drainage-area ratio method can be found in Ries (2007). Detailed descriptions can be found in Bodhaine (1968), Dalrymple and Benson (1968), Davidian (1984), and Matthai (1967). Because many factors associated with the indirect computation of streamflow (slopearea method and drainage-area ratio method) can have various levels of accuracy, and because the methods can depend considerably on engineering judgment, estimates may have large errors associated with them (Rantz and others, 1982; Ries, 2007).

For the community of Pine Island, streamflow was computed for the North Branch and the Middle Fork Zumbro River by the MDNR using the HEC-RAS version 4.1 water-surface profile model (U.S. Army Corps of Engineers, 2010). The steady-flow component of the modeling system was used to 


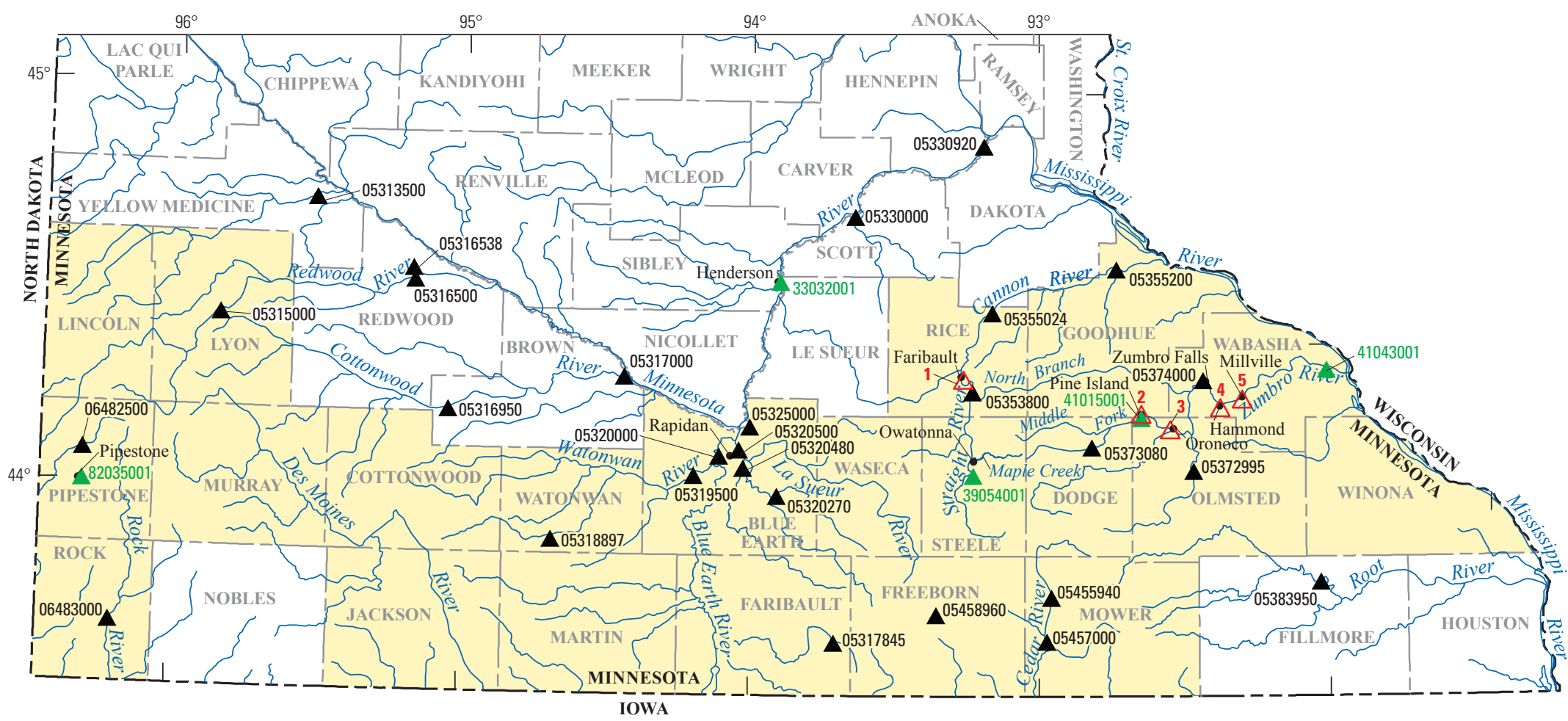

Base from Minnesota Department of Natural Resources, 1993, 1:24,000 and 1:100,000 and U.S. Geological Survey digital data, 1:2,000,000 Universal Transverse Mercator projection, Zone 15

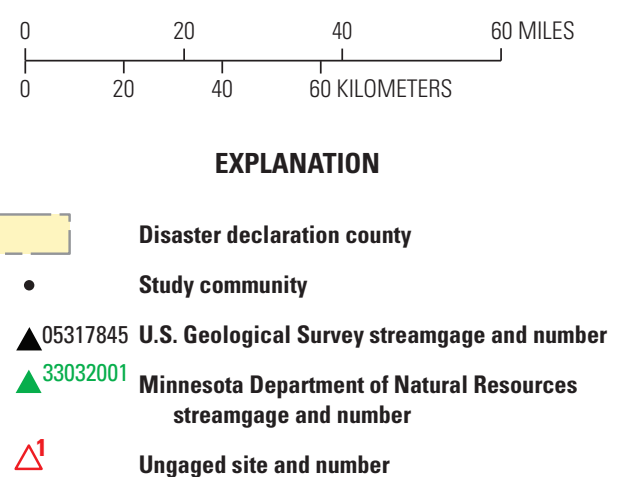

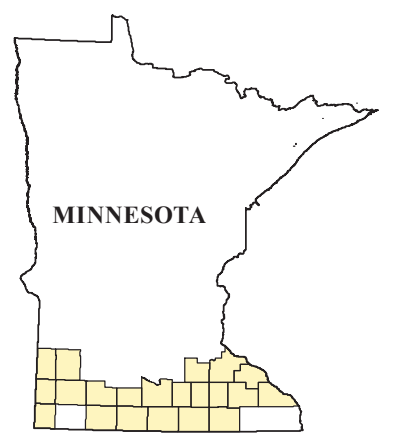

Figure 4. Locations of selected U.S. Geological Survey and Minnesota Department of Natural Resources streamgages and ungaged sites. 
calculate water-surface elevations for steady gradually varied flow for a range of streamflows. A stage-discharge rating curve then was plotted using the computed elevations for the range of streamflows. Using this rating curve for a given stage, the computed peak streamflow was determined from known elevations/stages at the height of flooding.

\section{Estimating Annual Exceedance Probabilities of Peak Streamflows}

The annual exceedance probability for a particular streamflow is the probability of that streamflow being equaled or exceeded in any given year. For example, a probability of 0.01 means there is a 1-percent chance of that streamflow magnitude being equaled or exceeded in any given year. The traditional concept of recurrence interval is related directly to the annual exceedance probability. By definition, the recurrence interval corresponding to a particular annual exceedance probability is equal to 1 divided by the annual exceedance probability (American Society of Civil Engineers, 1953; Hodgkins and others, 2007). For example, the annual exceedance probability of 0.01 corresponds to the 100 -year flood or 100 -year recurrence interval.

Annual exceedance probabilities associated with peak streamflows for 32 active streamgages and 5 ungaged locations were estimated to indicate the relative magnitude of the September 2010 floods. Streamflows for selected annual exceedance probabilities $(0.10,0.04,0.02,0.01$, and 0.002$)$ were estimated by using one of three methods: (1) the procedure presented by the Interagency Advisory Committee on Water Data (1982), commonly called the Bulletin 17B procedure, (2) regional regression equations for rural conditions (Lorenz and others, 2009), or (3) the Expected Moments Algorithm (Cohn and others, 1997). Users of the Bulletin 17B procedure and regional regression equations for rural conditions calculate flood probabilities by fitting systematic annual peak-streamflow data to a log-Pearson type III (LPIII) distribution. The Expected Moments Algorithm is a generalization of the procedures in Bulletin 17B and was designed to better accommodate historical peak-flow data (known peak flows outside the period of continuous streamflow data collection) and left-censored data (peak flows less than what can be measured at the streamgage).

Streamflow magnitudes associated with selected annual exceedance probabilities then can be used to estimate the range of annual exceedance probabilities for a particular flood. The upper and lower bounds for the range of probabilities are determined by comparing a particular peak streamflow (in this case, the peak streamflow from the 2010 flood) directly to streamflow magnitudes associated with the selected annual exceedance probabilities.

\section{Collection of High-Water-Mark Data}

High-water marks were identified and flagged by the USGS and MDNR in the four communities of Faribault, Owatonna, Pine Island, and Zumbro Falls along six streams: North Branch, Middle Fork Zumbro River, Zumbro River, Cannon River, Straight River, and Maple Creek (fig. 1, appendix 1). The high-water marks were identified and flagged during October and November 2010 after floodwaters receded. Highwater marks were identified and flagged on both sides of each stream at spacings of approximately 500 to 1,000 feet (ft), in accordance with standard USGS methods (Benson and Dalrymple, 1967). Commonly, stain lines on buildings, trees, or other structures were used to identify the highest level reached by the flooding waters. High-water marks were mapped and photographed, and site diagrams with associated information were recorded. The quality of the high-water marks was subjectively rated in the field as excellent, good, fair, or poor by the high-water-mark crews. Ratings were based on the clarity of the mark and visual or hand-level comparison to nearby marks.

High-water marks were surveyed during November using a Real-Time Kinematic Global Positioning System (RTK-GPS). Quality-assurance procedures included setting up the RTK-GPS base station at a high location (roof of county court house, municipal building, school, and so forth) for maximum satellite reception and radio coverage, and locating a minimum of two control points with multiple repeated readings (Vertical Second Order Class I; preferred) (Fitzpatrick and others, 2008). The preferred method of surveying a highwater mark was to set the RTK-GPS rover on the high-water mark and collect fixed-point data. If tree cover or building interference did not allow a fixed solution on the high-water mark, data for an intermediate survey point were collected a short distance away. In this case, the elevation of the desired high-water mark was determined by extending the elevation of the high-water mark to the intermediate survey point by using a hand level or string level. The difference in horizontal position between the intermediate point and the desired high-water mark was entered into the RTK-GPS unit using an estimated azimuth and distance to adjust the surveyed intermediate horizontal position to the actual high-water mark. The highwater marks were surveyed to an expected accuracy of $0.1 \mathrm{ft}$. The datum used was the North American Vertical Datum of 1988 (NAVD 88). High-water-mark descriptions, locations (latitude and longitude), and quality ratings are presented in appendix 1. 


\section{Flood-Peak Inundation Maps}

Flood-peak inundation maps were produced by use of geographic information system (GIS) software and associated programs (Morlock and others, 2008; Fitzpatrick and others, 2008; Fowler and others, 2010). These maps show the maximum extent of floodwaters in and around a community. GIS layers of the high-water-mark elevations (NAVD 88) and locations (latitude and longitude) in North American Datum of 1983 (NAD 83) were used in conjunction with LiDAR-based 1-meter land-surface elevation data files. LiDAR, an acronym for "light detection and ranging," is remote sensing technology that is based on discrete light pulses and measured travel times. It is used to generate highly accurate three-dimensional representations of the Earth's surface, termed "digital elevation models" (DEMs) (National Oceanic and Atmospheric Administration, 2008). These DEMs were used to develop the inundation maps, which then were superimposed on the corresponding National Agricultural Imagery Program aerial imagery (U.S. Department of Agriculture, 2009).

A GIS application was used to produce a plane representing the flood-peak water surface. The application duplicates the high-water-mark elevation data points across the flood plain perpendicular to the direction of the flood flow (Moon Kim, U.S. Geological Survey, written commun., January 2011). Elevations between high-water marks are proportional interpolations of the high-water-mark data and were positioned to generate a flood surface sloping with the water flow. A triangular irregular network (TIN) surface was created with the data points (TIN-generated surfaces pass exactly through the data-point elevations), forming the estimated flood surface. The flood-peak inundation areas are available in a GIS format that provides the extent of the flood peak. This format allows the GIS data to be overlain on maps and aerial photographs, and to be used for various GIS applications, such as FEMA's Hazards U.S. Multi-Hazards (HAZUS-MH) program (Federal Emergency Management Agency, 2010b) to estimate flood damages.

\section{Flood-Peak Water-Surface Profiles}

Standard USGS methods were used to develop floodpeak water-surface profiles from the high-water-mark elevations and locations (Benson and Dalrymple, 1967; Lumia and others, 1986). Flood profiles were produced for seven stream reaches by plotting high-water-mark elevations by mile of stream as measured upstream on the centerline of the thalweg from the downstream boundary of each study reach. The water surface between high-water marks was estimated by linear interpolation. A linear interpolation between high-water marks is an approximation of the actual water surface. The river-mile location of the high-water marks was calculated by the GISbased programs.

\section{Floods of September 2010 in Southern Minnesota}

The magnitudes and estimated annual exceedance probabilities of peak streamflows for the floods of September 2010 are presented in this section of the report. Flood-peak inundation maps and flood-peak water-surface profiles also are presented.

\section{Magnitudes and Estimated Annual Exceedance Probabilities of Peak Streamflows}

The magnitudes (flood-peak gage-height data and peakstreamflow data) and estimated annual exceedance probabilities from the September 2010 floods are presented for 32 active streamgages (table 2) and 5 ungaged sites (table 3 ). Locations of streamgages and ungaged sites are shown in figure 4. New peak-of-record streamflows were observed at 12 active streamgages. Most streams rose and fell rapidly beginning on September 23 (fig. 5). Large streams took longer to peak; the Straight River near Faribault peaked on September 24, whereas the Minnesota River near Jordan peaked on September 30. For 3 of the 31 active streamgages (USGS streamgage 05330920, USGS/MDNR streamgage 05326450/33032001, and MDNR streamgage 82035001), annual exceedance probabilities could not be estimated using the Bulletin 17B procedure or from regional regression equations either because the period of record was less than the minimum required 10 years of peak-flow data or because one or more basin characteristics were beyond the range used for development of models from regression analysis (Lorenz and others, 2009). For two USGS streamgages (05383950 and 05455940) and five ungaged sites, annual exceedance probabilities were obtained by use of regional regression equations for rural conditions (Lorenz and others, 2009). For two USGS streamgages (05318897 and 05355024), annual exceedance probabilities were determined by use of the Expected Moments Algorithm (Cohn and others, 1997). For the streamgages and ungaged sites where annual exceedance probabilities could be computed ( 34 of 37 sites), the estimated annual exceedance probabilities were less than 0.2 percent for 7 streamgages, and between 0.2 and 1 percent for 9 locations ( 5 streamgages and 4 ungaged sites; tables 2 and 3 ). 
Table 2. Flood-peak gage heights, peak streamflows, and annual exceedance probabilities of peak streamflows during the floods of September 2010 at selected U.S. Geological Survey and Minnesota Department of Natural Resources streamgages in Minnesota.

$\left[\mathrm{mi}^{2}\right.$, square miles; ft, feet; NGVD 29, National Geodetic Vertical Datum of 1929; ft³/s, cubic feet per second; \%, percent; USGS, U.S. Geological Survey; $>$, greater than; <, less than; MDNR, Minnesota Department of Natural Resources; --, data not available]

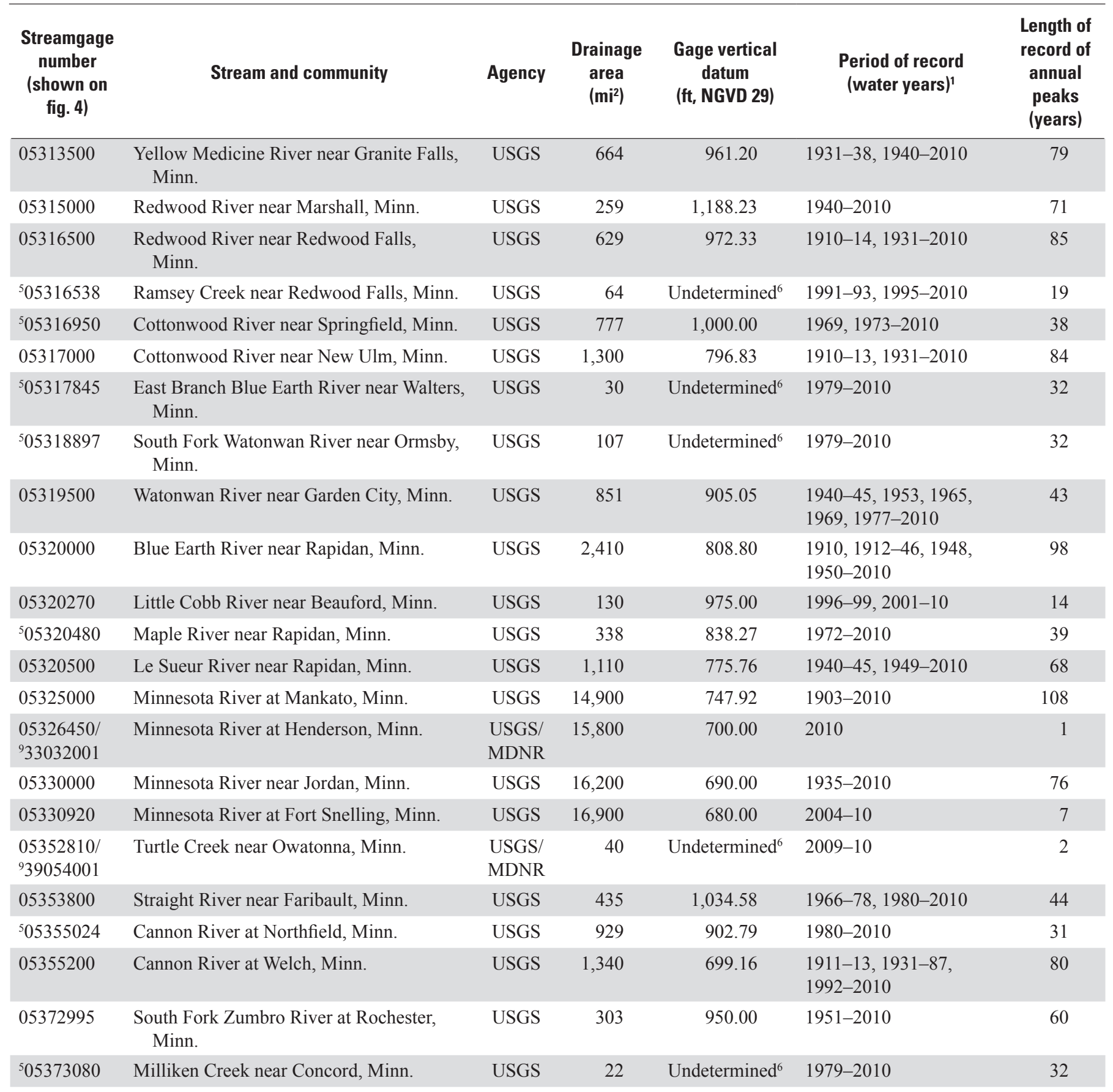




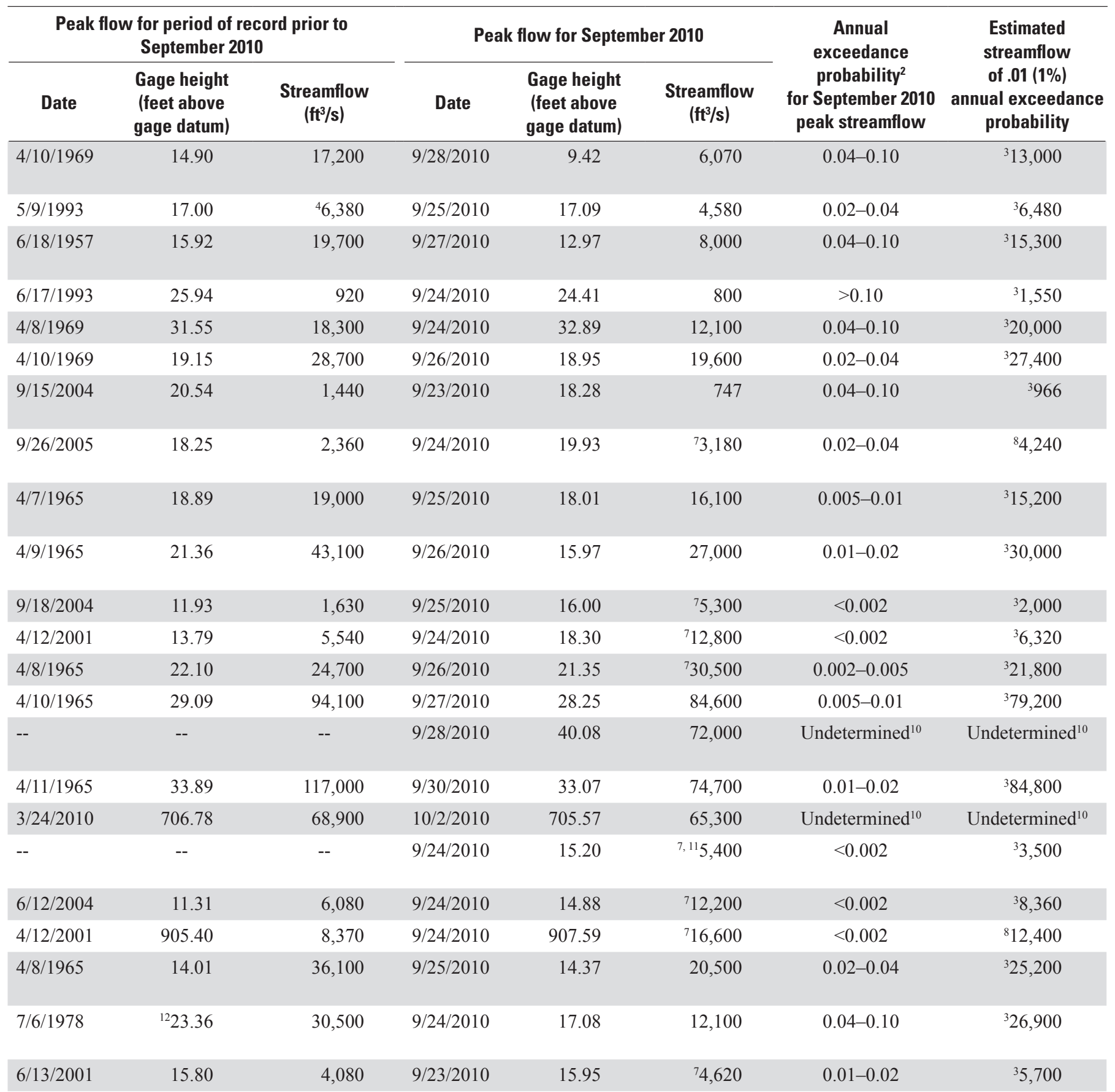


Table 2. Flood-peak gage heights, peak streamflows, and annual exceedance probabilities of peak streamflows during the floods of September 2010 at selected U.S. Geological Survey (USGS) and Minnesota Department of Natural Resources (MDNR) streamgages in Minnesota.-Continued

$\left[\mathrm{mi}^{2}\right.$, square miles; ft, feet; NGVD 29, National Geodetic Vertical Datum of 1929; $\mathrm{ft}^{3} / \mathrm{s}$, cubic feet per second; >, greater than; <, less than; \%, percent; USGS, U.S. Geological Survey; MDNR, Minnesota Department of natural Resources; --, data not available]

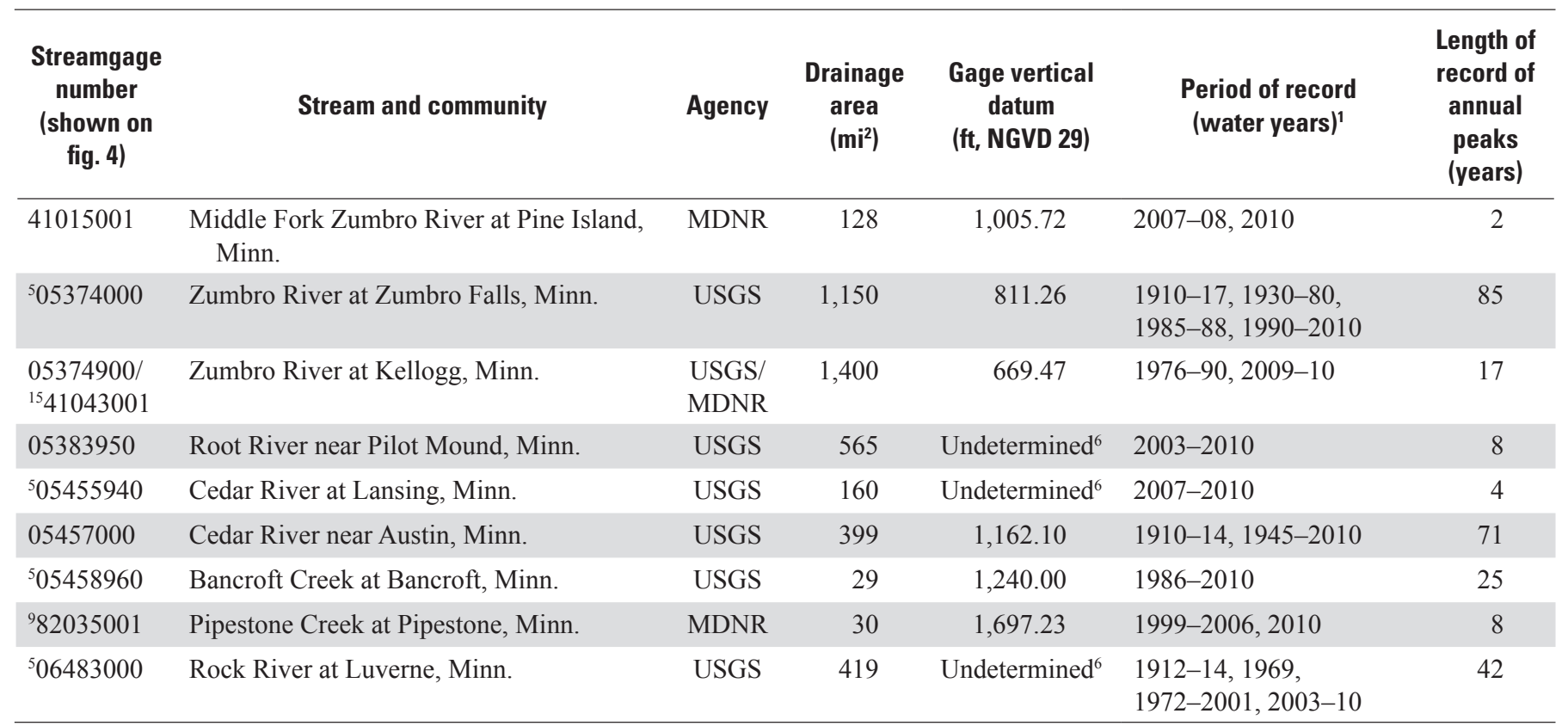

${ }^{1} \mathrm{~A}$ water year is the 12-month period from October 1 through September 30 and is designated by the calendar year in which it ends.

${ }^{2}$ The annual exceedance probability is the probability that a given event magnitude will be equaled or exceeded in any given year and is the reciprocal of the recurrence interval. The recurrence interval is the average interval of time within which the given flood will be equaled or exceeded once (American Society of Civil Engineers, 1953 , p. 1,221). The annual exceedance probability for a recurrence interval of 10 years is $0.10(10 \%)$; for 25 years, $0.04(4 \%)$; for 50 years, $0.02(2 \%)$; for 100 years, $0.01(1 \%)$; 200 years, $0.005(0.5 \%)$ and 500 years $0.002(0.2 \%)$.

${ }^{3}$ Streamflow computed from Bulletin 17B (Interagency Advisory Committee on Water Data, 1982).

${ }^{4}$ Streamflow affected to unknown degree by regulation or diversion.

${ }^{5}$ U.S. Geological Survey crest-stage or peak-stage gage.

${ }^{6}$ Elevation from vertical datum has not been established.

${ }^{7}$ New streamflow peak stage of record.

${ }^{8}$ Streamflow computed from Expected Moments Algorithm (Cohn and others, 1997).

${ }^{9}$ Minnesota Department of Natural Resources streamgage. Streamgage was installed by USGS technicians for the MDNR streamgage program and was assigned a USGS streamgage number.

${ }^{10}$ Recurrence-interval flows have not been established. One or more basin characteristics are beyond the range used for development of models from regression analysis.

${ }^{11}$ Streamflow computed using the slope-area method (Dalrymple and Benson, 1968).

${ }^{12}$ Gage height at different site and (or) datum.

${ }^{13}$ Streamflow computed by using Hydrologic Engineering Center River Analysis System water-surface profile model (U.S. Army Corps of Engineers, 2010).

${ }^{14}$ Streamflow from regional regression equations in Lorenz and others (2009).

${ }^{15}$ Minnesota Department of Natural Resources streamgage from 2009-10.

${ }^{16}$ Streamflow is an estimate. 


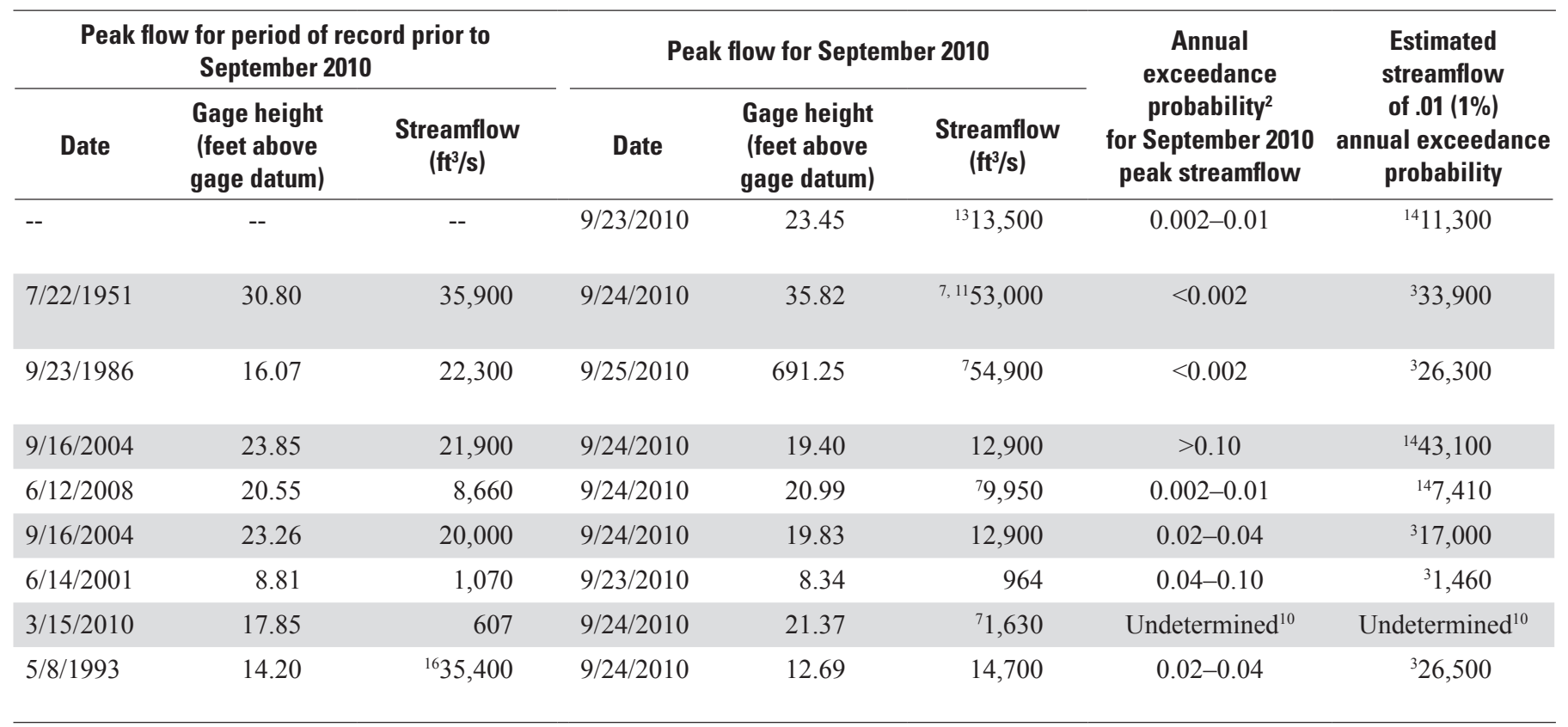


Table 3. Peak streamflows and estimated annual exceedance probabilities during the floods of September 2010, at selected ungaged locations in Minnesota.

$\left[\mathrm{mi}^{2}\right.$, square miles; $\mathrm{ft}^{3} / \mathrm{s}$, cubic feet per second; <, less than; \%, percent; --, none]

\begin{tabular}{|c|c|c|c|c|c|c|c|c|c|c|}
\hline \multirow{2}{*}{$\begin{array}{c}\text { Site } \\
\text { number } \\
\text { (shown on } \\
\text { fig. 4) }\end{array}$} & \multirow[b]{2}{*}{$\begin{array}{l}\text { Stream and } \\
\text { community }\end{array}$} & \multirow[b]{2}{*}{ County } & \multirow{2}{*}{$\begin{array}{c}\text { Drainage } \\
\text { area } \\
\text { at site } \\
\left(\mathrm{mi}^{2}\right)\end{array}$} & \multicolumn{4}{|c|}{$\begin{array}{c}\text { Peak flow }\left(\mathrm{ft}^{3} / \mathrm{s}\right) \text { for given } \\
\text { annual exceedance probability }\end{array}$} & \multicolumn{3}{|c|}{ Peak flow during September flood } \\
\hline & & & & 0.10 & 0.04 & 0.02 & 0.01 & $\begin{array}{l}\text { Peak } \\
\text { flow } \\
\left(\mathrm{ft}^{3} / \mathrm{s}\right)\end{array}$ & $\begin{array}{l}\text { Estimated } \\
\text { annual } \\
\text { exceedance } \\
\text { probability }\end{array}$ & Comment \\
\hline 1 & $\begin{array}{l}\text { Straight River at Faribault, } \\
\text { Minn. }\end{array}$ & Rice & 460 & 25,650 & ${ }^{2} 8,140$ & ${ }^{2} 10,300$ & ${ }^{2} 12,700$ & ${ }^{3} 12,900$ & $<0.01$ & Peak flow $2 \%$ greater than 100 -year flood. \\
\hline 2 & $\begin{array}{l}\text { North Branch River at Pine } \\
\text { Island, Minn. }\end{array}$ & Goodhue & 58 & 23,460 & 24,760 & ${ }^{2} 5,790$ & ${ }^{2} 6,930$ & ${ }^{4} 6,500$ & $0.01-0.02$ & -- \\
\hline 3 & $\begin{array}{l}\text { Middle Fork Zumbro River } \\
\text { at Oronoco, Minn. }\end{array}$ & Olmsted & 206 & 27,580 & ${ }^{2} 10,400$ & ${ }^{2} 12,600$ & ${ }^{2} 15,100$ & ${ }^{3} 21,700$ & $<0.01$ & Peak flow $44 \%$ greater than 100 -year flood. \\
\hline 4 & $\begin{array}{l}\text { Zumbro River at } \\
\text { Hammond, Minn. }\end{array}$ & Wabasha & 1,160 & ${ }^{2} 21,400$ & ${ }^{2} 29,000$ & 234,700 & ${ }^{2} 40,900$ & ${ }^{3} 52,000$ & $<0.01$ & Peak flow $27 \%$ greater than 100 -year flood. \\
\hline 5 & $\begin{array}{l}\text { Zumbro River at Millville, } \\
\text { Minn. }\end{array}$ & Wabasha & 1,200 & ${ }^{2} 21,900$ & 229,600 & 235,400 & ${ }^{2} 41,800$ & 353,800 & $<0.01$ & Peak flow $29 \%$ greater than 100 -year flood. \\
\hline
\end{tabular}

${ }^{1}$ The annual exceedance probability is the probability that a given event magnitude will be equaled or exceeded in any given year (the reciprocal of the recurrence interval). The recurrence interval is the average interval of time within which the given flood will be equaled or exceeded once (American Society of Civil Engineers, 1953, p. 1,221). The annual exceedance probability for a recurrence interval of 10 years is $0.10(10 \%)$; for 25 years, $0.04(4 \%)$; for 50 years, $0.02(2 \%)$; and for 100 years, $0.01(1 \%)$.

${ }^{2}$ Streamflow from Lorenz and others (2009).

${ }^{3}$ Streamflow estimated using drainage-area ratio method (Ries, 2007).

${ }^{4}$ Streamflow computed using Hydrologic Engineering Center River Analysis System water-surface profile model (U.S. Army Corps of Engineers, 2010). 


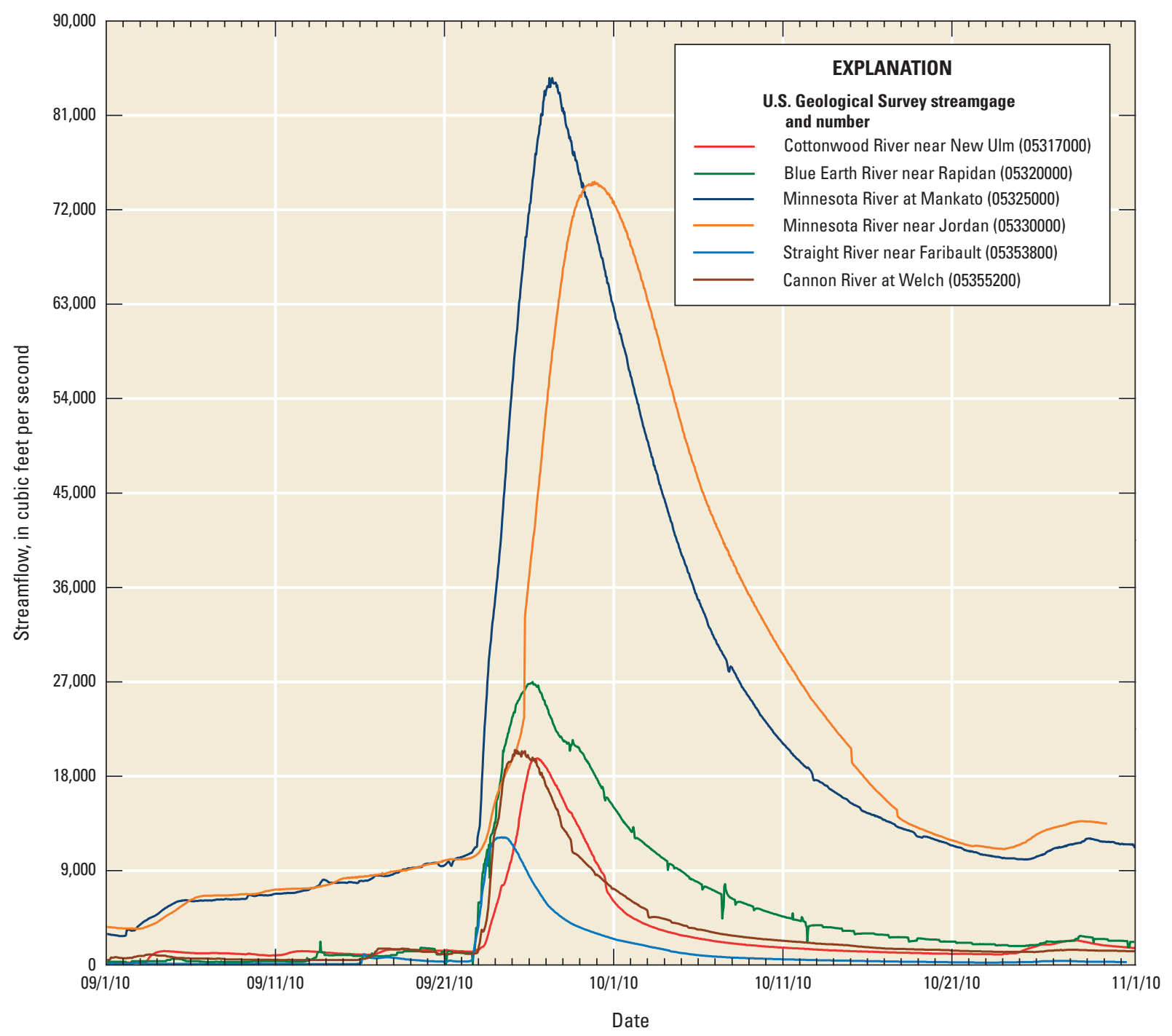

Figure 5. Hydrographs showing selected U.S. Geological Survey streamgages in southern Minnesota for September through October 2010 (locations of streamgages shown on figure 4).

\section{Flood-Peak Inundation Maps and Water-Surface Profiles}

Flood-peak inundation maps and flood-peak watersurface profiles were produced for the four communities of Faribault (Cannon and Straight Rivers), Owatonna (Straight River and Maple Creek), Pine Island (North Branch and Middle Fork Zumbro River), and Zumbro Falls (Zumbro River). Personnel from the USGS and MDNR flagged and surveyed 43 high-water marks along a total of 11 stream miles in October and November 2010 in the four most severely affected communities. A descriptive table of high-water marks used in the inundation mapping is listed in appendix 1 .

A flood-peak inundation map was generated for each community showing the maximum extent and height of floodwaters in and around the community; the four maps are presented in appendix 2 . Inundation maps also contain locations and elevations of high-water marks used to develop the map. The maps were checked by USGS surveying and highwater-mark personnel, and the high-water marks were compared spatially to check for mathematical or other errors. If a data point was too high or too low when compared to neighboring points, the point in question was removed from the inundation map. For example, high-water marks PI1 and PI7 (appendix 1) in the community of Pine Island were removed from the inundation map because they did not compare well spatially with high-water mark PI2. High-water mark PI2 was a well-defined seed line and was rated good quality by field personnel. In contrast, PI1 was based on a homeowner's recollection of the high-water mark, and PI7 was based on a debris line; both received poor quality ratings by field personnel. 
Seven flood-peak water-surface profiles are provided in appendix 3. Flood-peak profiles show how the flood-peak inundation surface and slope varied along the stream reach through each of the four communities. Locations of street crossings and important landmarks were added to the profiles to provide additional context.

\section{Description of Flood Damages and Effects}

Heavy rainfall on a landscape already wet from antecedent conditions caused widespread record flooding in southern Minnesota in September 2010. Power outages, evacuations, and major transportation disruptions affected thousands of southern Minnesota residents and caused damage in excess of 64 million dollars to homes, businesses, and infrastructure (Bruce Gordon, Minnesota Department of Public Safety, written commun., February 2011).

Flooding was most extensive in the communities of Faribault, Owatonna, Pine Island, and Zumbro Falls as local rivers, creeks, and ditches rose rapidly during September 22 through 25,2010 . In addition to these communities, but to a lesser degree, the communities of Hammond, Henderson, Millville, Oronoco, Pipestone, and Rapidan (fig. 1) also had extensive flooding and damages. Zumbro Falls, a town with a population of 177 located adjacent to the Zumbro River, was inundated by record streamflow in the early hours of September 25. The previous records for stage and streamflow, set in 1951 for the Zumbro River at Zumbro Falls (streamgage 05374000; fig. 4), with a river stage of $30.8 \mathrm{ft}$ and associated streamflow of 35,900 cubic feet per second $\left(\mathrm{ft}^{3} / \mathrm{s}\right)$, were exceeded by $5 \mathrm{ft}$ in stage $(35.82 \mathrm{ft})$ and more than 17,000 cubic feet per second $\left(53,000 \mathrm{ft}^{3} / \mathrm{s}\right)$ in streamflow (table 2). The annual exceedance probability for the 2010 flood at this streamgage was less than 0.2 percent (greater than a 500-year recurrence interval). In the downtown area of Zumbro Falls, 58 homes and 20 of the 26 businesses were classified as destroyed. Downstream from Zumbro Falls, the banks of the Zumbro River suffered massive bank failure at Kellogg (USGS/MDNR streamgage 05374900/41043001; fig. 4, table 2), endangering several homes when $40 \mathrm{ft}$ of nearby homeowners' yards eroded away when the saturated banks collapsed. The community of Pine Island also experienced major flooding. In Pine Island, more than 100 homes were affected, with damage varying from water in basements to water over the main floor structure. Additionally, more than 20 businesses were damaged and numerous roads and culverts were washed out.

In southwestern Minnesota, Pipestone Creek at Pipestone (MDNR streamgage 82035001), peaked on September 24 at stages and streamflow that exceeded the previous records (table 2). The city's wastewater system was overwhelmed with water. At the height of the flood, the city's main lift station was pumping 3,000 gallons of water per minute, compared to
1,100 gallons per minute during typical operations (Pipestone County Star Online, 2010). The communities of Faribault and Owatonna on the Straight River also had record streamflows. Upstream from Faribault, the Straight River (USGS streamgage 05353800 ) peaked on September 24 at approximately twice the previous record streamflow $\left(12,200 \mathrm{ft}^{3} / \mathrm{s}\right.$ on September 24, 2010, compared to $6,080 \mathrm{ft}^{3} / \mathrm{s}$ on June 12, 2004) (table 2). Streamflow on the Straight River near Faribault had an annual exceedance probability of less than 0.2 percent. Farther upstream from Faribault on the Straight River, the community of Owatonna also received extensive flooding. More than 200 homes around Owatonna were evacuated or affected by the flooding and more than 70 county roads and city streets were closed at the height of flooding (Minnesota State Emergency Operations Center, 2010).

The following is a summary of damage assessment compiled after September 2010:

- More than 600 dwellings were affected with 101 properties suffering major damage, 280 suffering minor damage, and 80 properties classified as destroyed (Bruce Gordon, Minnesota Department of Public Safety, written commun., February 2011).

- The Shady Lake Dam failed in Olmsted County near the town of Oronoco (Minnesota State Emergency Operations Center, 2010).

- More than 200 evacuations and water rescues were made during the flooding.

- More than 100 Minnesota National Guard Soldiers and Airmen supported relief missions.

- More than 360 Red Cross Staff and volunteers provided 242 overnight stays at 11 shelters, distributed approximately 2,400 clean-up kits, and provided more than 23,000 meals to residents, emergency workers, and clean-up volunteers; donations from the Red Cross were estimated at more than 800 thousand dollars (American Red Cross Southeast Minnesota Chapter, 2010).

- Food and drinking-water distribution points were set up in the affected counties.

- Levee damage occurred along the Blue Earth River in Mankato (Blue Earth County) (Minnesota State Emergency Operations Center, 2010).

- Main electric transmission lines were damaged.

- Transportation disruptions were widespread. Highway 169 (Blue Earth County) between Mankato and Henderson was closed for 2 weeks because of high water and road damage. In Steele County, more than 70 county roads and city streets were closed at the height of flooding (Minnesota State Emergency Operations Center, 2010). 
- Ten school districts reported flood-related facility damage totaling an estimated 960 thousand dollars (Minnesota State Emergency Operations Center, 2010).

On October 13, 2010, President Obama declared that a major disaster existed in southern Minnesota (Federal Emergency Management Agency, 2010a). The disaster declaration brought much needed additional assistance for residents and businesses. This declaration made Public Assistance requested by the Governor available to State and eligible local governments, and certain private nonprofit organizations on a costsharing basis for emergency work and the repair or replacement of facilities damaged by the severe flooding in Blue Earth, Cottonwood, Dodge, Faribault, Freeborn, Goodhue, Jackson, Lincoln, Lyon, Martin, Mower, Murray, Olmsted, Pipestone, Rice, Rock, Steele, Wabasha, Waseca, Watonwan, and Winona Counties. Direct Federal assistance also was authorized. Finally, this declaration made Hazard Mitigation Grant Program assistance requested by the Governor available for hazard-mitigation measures statewide.

\section{Summary}

During September 22-24, 2010, heavy rainfall ranging from 3 inches to more than 10 inches caused severe flooding across southern Minnesota. The floods were exacerbated by wet antecedent conditions, where summer rainfall totals were as high as 20 inches, exceeding the historical average by more than 4 inches. Widespread flooding that occurred as a result of the heavy rainfall caused evacuations of hundreds of residents, and damages in excess of 64 million dollars to residences, businesses, and infrastructure. In all, 21 counties in southern Minnesota were declared Federal disaster areas.

The 72-hour rainfall amounts in September 2010 had an annual exceedance probability of less than 1 percent (recurrence interval greater than 100 years) at several National Weather Service precipitation stations. Given the severity of the flooding, the U.S. Geological Survey (USGS), in cooperation with the Federal Emergency Management Agency and the Minnesota Department of Natural Resources (MDNR), Division of Ecological and Water Resources, conducted a study to document the meteorological and hydrological conditions leading to the flood; compile flood-peak gage heights, streamflows, and annual exceedance probabilities at selected USGS and MDNR streamgages and ungaged sites; construct floodpeak inundation maps and flood-peak water-surface profiles; and summarize flood damages and effects.

Peak-of-record streamflows were recorded at nine USGS and three MDNR streamgages as a result of the heavy rainfall. Flood-peak gage heights, peak streamflows, and annual exceedance probabilities were tabulated for 27 USGS and 5 MDNR streamgages and 5 ungaged sites. Flood-peak streamflows had annual exceedance probabilities estimated to be less than 0.2 percent (recurrence interval greater than 500 years) at 7 streamgages and less than 1 percent (recurrence interval greater than 100 years) at 5 streamgages and 4 ungaged sites. The USGS and MDNR flagged and surveyed 43 high-water marks along a total of 11 stream miles in October and November 2010 in 4 communities of Faribault along the Cannon and Straight Rivers, Owatonna along the Straight River and Maple Creek, Pine Island along the North Branch and Middle Fork Zumbro River, and Zumbro Falls along the Zumbro River. The nearby communities of Hammond, Henderson, Millville, Oronoco, Pipestone, and Rapidan also received extensive flooding and damage but were not surveyed for high-water marks.

Flood-peak inundation maps and water-surface profiles for the four most severely affected communities were constructed in a geographic information system by combining high-water-mark data with the highest resolution digital elevation model data available. The flood maps and profiles show the extent and height of flooding through the communities and can be used for flood response and recovery efforts by local, county, State, and Federal agencies.

\section{References Cited}

American Red Cross Southeastern Minnesota Chapter, 2010, Disaster update-Red Cross continues helping southern Minnesota families devastated by floods, accessed February 4, 2011, at http://www.redcrosstc.org/detalle_noticias. asp $?$ id $=6587 \& S N=10910 \& O P=10911 \& I D$ Capitulo $=073$ V3P7593.

American Society of Civil Engineers, 1953, Report of the subcommittee on the joint division committee on floods: American Society of Civil Engineers Transactions, v. 118, p. $1,220-1,230$.

Benson, M.A., and Dalrymple, Tate, 1967, General field and office procedures for indirect measurements: U.S. Geological Survey Techniques of Water-Resources Investigations, book 3 , chap. A1, $30 \mathrm{p}$.

Bodhaine, G.L., 1968, Measurement of peak discharge at culverts by indirect methods: U.S. Geological Survey Techniques of Water-Resources Investigations, book 3, chap. A3, $48 \mathrm{p}$.

Bureau of Land Management, 2011, Glossaries of BLM surveying and mapping terms, accessed February 23, 2011, at http://www.blm.gov/cadastral/Glossary/glossary.htm\#.

Charlton, Ro, 2009, Fundamentals of fluvial geomorphology: New York, Routledge, 234 p.

Cohn, T., Lane, W.L., and Baier, W.G., 1997, An algorithm for computing moments-based flood estimates when historical flood information is available: Water Resources Research, v. 33, no. 9, p. 2,089-2,096. 
Dalrymple, Tate, and Benson, M.A., 1968, Measurement of peak discharge by the slope-area method: U.S. Geological Survey Techniques of Water-Resources Investigations, book 3, chap. A2, 12 p.

Davidian, Jacob, 1984, Computation of water-surface profiles in open channels: U.S. Geological Survey Techniques of Water-Resources Investigations, book 3, chap. A15, 48 p.

Federal Emergency Management Agency, 2010a, 2010 Federal disaster declarations, accessed December 29, 2010, at http:// www.fema.gov/pdf/news/pda/1941.pdf.

Federal Emergency Management Agency, 2010b, HAZUS, accessed January 27, 2011, at http://www.fema.gov/plan/ prevent/hazus/.

Fitzpatrick, F.A., Peppler, M.C., Walker, J.F., Rose, W.J., Waschbusch, R.J., and Kennedy, J.L., 2008, Flood of June 2008, southern Wisconsin: U.S. Geological Survey Scientific Investigations Report 2008-5235, 24 p. (Also available at http://pubs.usgs.gov/sir/2008/5235/.)

Fowler, K.K., Kim, M.H., Menke, C.D., and Arvin, D.V., 2010, Flood of September 2008 in northwestern Indiana: U.S. Geological Survey Open-File Report 2010-1098, 20 p. (Also available at http://pubs.usgs.gov/of/2010/1098/.)

Fulford, J.M., 1995, User's guide to the Culvert Analysis Program: U.S. Geological Survey Open-File Report 95-137, $69 \mathrm{p}$.

Hodgkins, G.A., Stewart, G.J., Cohn, T.A., and Dudley, R.W., 2007, Estimated magnitudes and recurrence intervals of peak flows on the Mousam and Little Ossipee Rivers for the flood of April 2007 in southern Maine: U.S. Geological Survey Open-File Report 2007-1146, 5 p., accessed January 27, 2011, at http://pubs.usgs.gov/of/2007/1146/.

Huff, F.A., and Angel, J.R., 1992, Rainfall frequency atlas of the Midwest: Champaign, Illinois State Water Survey, Bulletin $71,141 \mathrm{p}$.

Interagency Advisory Committee on Water Data, 1982, Guidelines for determining flood flow frequency, Bulletin 17B of the Hydrology Subcommittee: Reston, Virginia, U.S. Geological Survey, Office of Water Data Coordination, 183 p.

Langbein, W.B., and Iseri, K.T., 1960, General introduction and hydrologic definitions, Manual of hydrology, part 1, General surface-water techniques: U.S. Geological Survey Water-Supply Paper 1541-A, 29 p.

Lorenz, D.L., Sanocki, C.A., and Kocian, M.J., 2009, Techniques for estimating the magnitude and frequency of peak flows on small streams in Minnesota based on data through water year 2005: U.S. Geological Survey Scientific Investigations Report 2009-5250, 54 p.
Lumia, Richard, Burke, P.M., and Johnston, W.H., 1986, Flooding of December 29, 1984, through January 2, 1985, in northern New York State, with flood profiles of the Black and Salmon Rivers: U.S. Geological Survey WaterResources Investigations Report 86-4191, 53 p.

Matthai, H.F., 1967, Measurement of peak discharge at width contractions by indirect methods: U.S. Geological Survey Techniques of Water-Resources Investigations, book 3, chap. A4, 44 p.

Minnesota Department of Natural Resources State Climatology Office, 2010a, Minnesota's wet summer, accessed January 2, 2011, at http://climate.umn.edu/doc/journal/wet_summer_2010.htm.

Minnesota Department of Natural Resources State Climatology Office, 2010b, Wet September 2010, accessed January 3, 2011, at http://climate.umn.edu/doc/journal/wet_september_2010.htm.

Minnesota Department of Natural Resources State Climatology Office, 2010c, Closest station climate data retrieval, accessed January 3, 2011, at http://climate.umn.edu/hidradius/radius.asp.

Minnesota State Emergency Operations Center, 2010, Situation reports, accessed January 24, 2011, at http://www.eoc. state.mn.us/Fall2010Flood/sitrep.asp.

Morlock, S.E., Menke, C.D., Arvin, D.V., and Kim, M.H., 2008, Flood of June 7-9, 2008, in central and southern Indiana: U.S. Geological Survey Open-File Report 2008-1322, 15 p., 3 app. (Also available at http://pubs.usgs.gov/ of/2008/1322/.)

National Oceanic and Atmospheric Administration, 2008, LIDAR 101-An introduction to LiDAR technology, data, and applications, accessed March 8, 2011, at http://www. csc.noaa.gov/digitalcoast/data/coastallidar/_pdf/What_is_ Lidar.pdf.

National Oceanic and Atmospheric Administration, 2010a, September 22-23, 2010 - Significant rainfall and widespread flooding across southern Minnesota and Wisconsin, accessed January 4, 2011, at http://www.crh.noaa.gov/ images/mpx/StormReports/23September2010.pdf.

National Oceanic and Atmospheric Administration, 2010b, Multi-Sensor QPE-Office of Hydrologic Development and National Mosaic \& Multi-Sensor NMQ (NSSL), Q2 System, 2010, accessed January 4, 2011, at http://www.nssl. noaa.gov/projects/q2/q2.php, data from http://nmq.ou.edu/ at QPE tab. 
National Weather Service, 2005, National Weather Service glossary, accessed January 3, 2010, at $h t t p: / / w w w . w e a t h e r$. gov/glossary/.

Pipestone County Star Online, 2010, Pipestone dries out, begins to assess damages, accessed January 13, 2011, at $h t t p: / / w w w$.pipestonestar.com/Stories/Story.cfm? $S I D=28302$.

Rantz, S.E., and others, 1982, Measurement and computation of streamflow-Volume 1, Measurement of stage and discharge, and volume 2, Computation of discharge: U.S. Geological Survey Water-Supply Paper 2175, 631 p.

Ries, K.G., III, 2007, The national streamflow statistics program-A computer program for estimating streamflow statistics for ungaged sites: U.S. Geological Survey Techniques and Methods 4-A6, $37 \mathrm{p}$.

Skinner, K.D., 2009, Evaluation of LiDAR-acquired bathymetric and topographic data accuracy in various hydrogeomorphic settings in the lower Boise River, southwestern Idaho, 2007: U.S. Geological Survey Scientific Investigations Report 2009-5260, 12 p.

U.S. Army Corps of Engineers, 2010, HEC-RAS, accessed February 4, 2011, at http://www.hec.usace.army.mil/ software/hec-ras/documents/HEC-RAS_4.1_Applications_ Guide.pdf.

U.S. Department of Agriculture, 2009, National Agricultural Imagery Program (NAIP) Digital Orthorectified Images (DOQ), Minnesota, 2009, accessed January 3, 2011, at http://www.mngeo.state.mn.us/chouse/metadata/naip09. html. 



\section{Glossary}

The following definitions, except where otherwise noted, are from Langbein and Iseri (1960).

annual exceedance probability The probability that a given event magnitude will be exceeded or equaled in any given year. The annual exceedance probability is directly related to the recurrence interval. For example, there is a 1-percent chance that the 100year peak flow will be exceeded or equaled in any given year. A flood probability of 0.01 has a recurrence interval of 100 years. The recurrence interval corresponding to a particular flood probability is equal to one divided by the flood probability.

azimuth The angle measured on the horizon between the meridian (north-south line) and the plane of the vertical circle through a celestial body (typically Polaris or Ursae Minoris in the northern hemisphere) or other object (Bureau of Land Management, 2011).

cubic feet per second A unit expressing rates of discharge. One cubic foot per second is equal to the discharge of a stream of rectangular cross section, 1 foot wide and 1 foot deep, flowing water an average velocity of 1 foot per second.

flood peak The highest value of the stage or discharge attained by a flood; thus, peak stage or peak discharge. "Flood crest" has nearly the same meaning, but because it connotes the top of the flood wave, it is properly used only in referring to stage - thus, "crest stage," but not "crest discharge."

flood plain A strip of relatively smooth land bordering a stream, built of sediment carried by the stream and dropped in the slack water beyond the influence of the swiftest current. It is called a living flood plain if it is overflowed in times of highwater, but a fossil flood plain if it is beyond the reach of the highest flood.

flood profile A graph of elevation of the water surface of a river in flood, plotted as ordinate, against distance, measured in the downstream direction, plotted as abscissa. A flood profile may be drawn to show elevation at a given time or crests during a particular flood. gage height The water-surface elevation referred to some arbitrary gage datum. Gage height is often used interchangeably with the more general term "stage," although gage height is more appropriate when used with a reading on a gage.

high-water mark The highest stage reached by a flood that has been maintained for a sufficient period to leave evidence on the landscape (Benson and Dalrymple, 1967).

LiDAR Remote-sensing technology that uses laser pulses to measure the distance from the laser to topographic and bathymetric surfaces (Skinner, 2009).

recurrence interval (return period) The average interval of time within which the given flood will be equaled or exceeded once. The recurrence interval is directly related to the flood probability. The recurrence interval corresponding to a particular flood probability is equal to 1 divided by the flood probability. For example, a 100-year recurrence interval has a flood probability of 0.01 .

stream A general term for a body of flowing water. In hydrology the term is generally applied to the water flowing in a natural channel as distinct from a canal.

streamflow The discharge that occurs in a natural channel. Although the term "discharge" can be applied to the flow of a canal, the word "streamflow" uniquely describes the discharge in a surface stream course.

streamgage A gaging station where a record of discharge of a stream is obtained. Within the U.S. Geological Survey this term is used only for those gaging stations where a continuous record of gage-height is obtained.

thalweg The area of maximum water velocity within a channel flow (Charlton, 2009).

warm front A transition zone between a mass of warm air and the colder air it is replacing (National Weather Service, 2005). 



\section{Appendix 1. High-Water-Mark Descriptions in the Communities of Faribault, Owatonna, Pine Island, and Zumbro Falls, Floods of September 2010, Minnesota}

Table 1-1. High-water-mark descriptions in the communities of Faribault, Owatonna, Pine Island, and Zumbro Falls, floods of September 2010, Minnesota.

[Vertical coordinate data are referenced to the North American Vertical Datum of 1988 (NAVD 1988). Horizontal coordinate data are referenced to the North American Datum of 1983. Approximate quality ratings of high-water marks: Excellent, \pm 0.02 foot; Good, \pm 0.05 foot; Fair, \pm 0.1 foot; and Poor, greater than 0.10 foot (Lumia and others, 1986); for bank of nearest stream, "right" and "left" refer to an observation looking in the downstream direction]

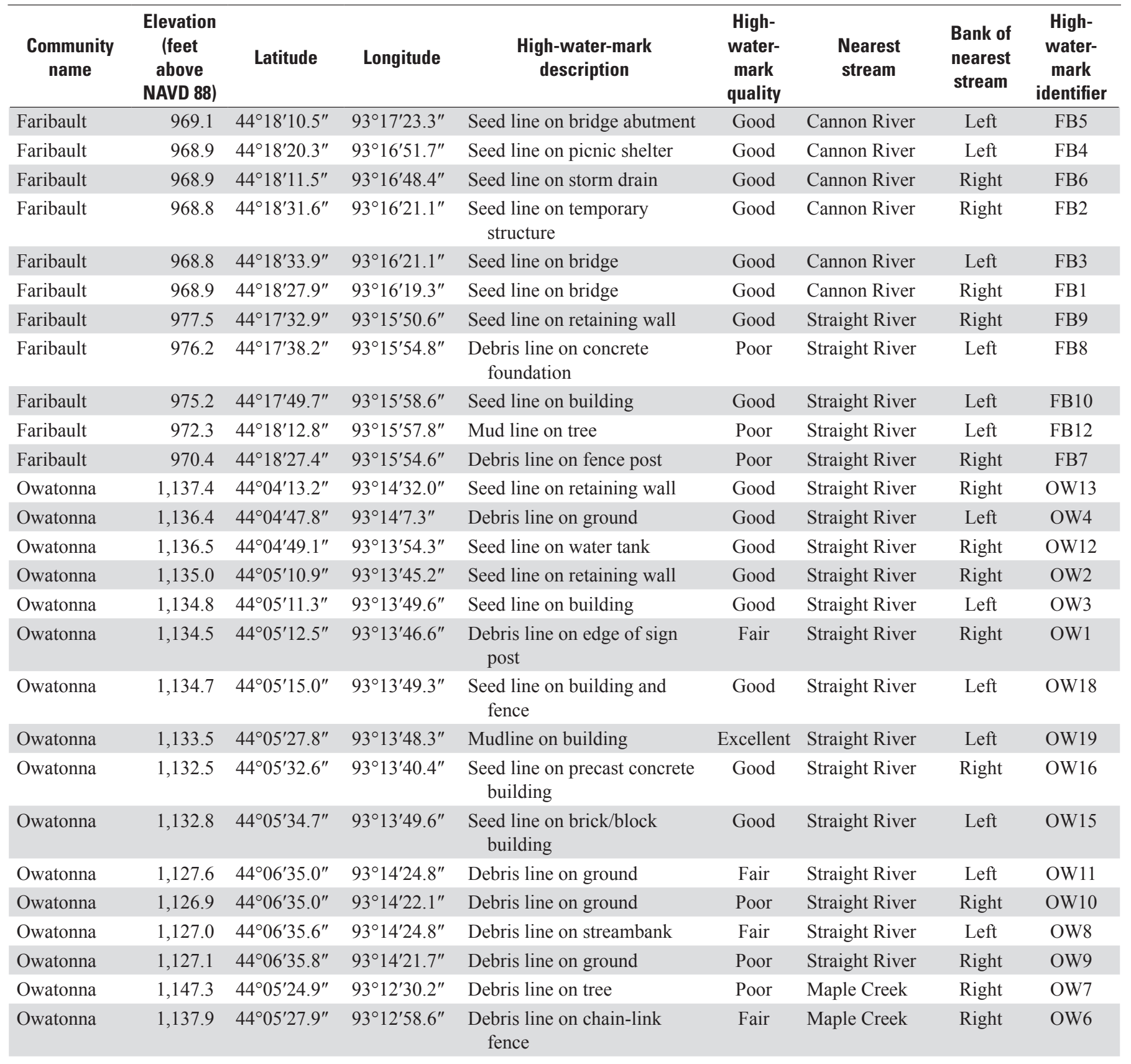


Table 1-1. High-water-mark descriptions in the communities of Faribault, Owatonna, Pine Island, and Zumbro Falls, floods of September 2010, Minnesota.-Continued

[Vertical coordinate data are referenced to the North American Vertical Datum of 1988 (NAVD 1988). Horizontal coordinate data are referenced to the North American Datum of 1983. Approximate quality ratings of high-water marks: Excellent, \pm 0.02 foot; Good, \pm 0.05 foot; Fair, \pm 0.1 foot; and Poor, greater than 0.10 foot (Lumia and others, 1986); for bank of nearest stream, "right" and "left" refer to an observation looking in the downstream direction]

\begin{tabular}{|c|c|c|c|c|c|c|c|c|}
\hline $\begin{array}{l}\text { Community } \\
\text { name }\end{array}$ & $\begin{array}{c}\text { Elevation } \\
\text { (feet } \\
\text { above } \\
\text { NAVD 88) }\end{array}$ & Latitude & Longitude & $\begin{array}{l}\text { High-water-mark } \\
\text { description }\end{array}$ & $\begin{array}{l}\text { High- } \\
\text { water- } \\
\text { mark } \\
\text { quality }\end{array}$ & $\begin{array}{l}\text { Nearest } \\
\text { stream }\end{array}$ & $\begin{array}{c}\text { Bank of } \\
\text { nearest } \\
\text { stream }\end{array}$ & $\begin{array}{c}\text { High- } \\
\text { water- } \\
\text { mark } \\
\text { identifier }\end{array}$ \\
\hline Pine Island & $1,002.7$ & $44^{\circ} 11^{\prime} 33.5^{\prime \prime}$ & $92^{\circ} 38^{\prime} 54.4^{\prime \prime}$ & Mudline on bridge & Poor & $\begin{array}{l}\text { Middle Fork } \\
\text { Zumbro } \\
\text { River }\end{array}$ & Right & PI9 \\
\hline Pine Island & 995.5 & $44^{\circ} 11^{\prime} 57.2^{\prime \prime}$ & $92^{\circ} 38^{\prime} 28.9^{\prime \prime}$ & $\begin{array}{l}\text { Mudline on house/home- } \\
\text { owner's mark }\end{array}$ & Poor & $\begin{array}{l}\text { Middle Fork } \\
\text { Zumbro } \\
\text { River }\end{array}$ & Left & PI1 \\
\hline Pine Island & 995.8 & $44^{\circ} 12^{\prime} 10.0^{\prime \prime}$ & $92^{\circ} 38^{\prime} 23.4^{\prime \prime}$ & Seedline on pet shelter & Good & $\begin{array}{l}\text { Middle Fork } \\
\text { Zumbro } \\
\text { River }\end{array}$ & Left & PI5 \\
\hline Pine Island & $1,000.1$ & $44^{\circ} 12^{\prime} 23.5^{\prime \prime}$ & $92^{\circ} 39^{\prime} 5.2^{\prime \prime}$ & Debris line on tree & Poor & North Branch & Left & PI8 \\
\hline Pine Island & 996.3 & $44^{\circ} 12^{\prime} 11.5^{\prime \prime}$ & $92^{\circ} 38^{\prime} 40.3^{\prime \prime}$ & Water line on picnic shelter & Fair & North Branch & Left & PI4 \\
\hline Zumbro Falls & 846.8 & $44^{\circ} 17^{\prime} 6.4^{\prime \prime}$ & $92^{\circ} 25^{\prime} 53.6^{\prime \prime}$ & Mudline on house & Good & Zumbro River & Right & ZF6 \\
\hline Zumbro Falls & 846.4 & $44^{\circ} 17^{\prime} 8.9^{\prime \prime}$ & $92^{\circ} 25^{\prime} 47.3^{\prime \prime}$ & Mudline on bridge abutment & Good & Zumbro River & Left & ZF1 \\
\hline Zumbro Falls & 845.2 & $44^{\circ} 16^{\prime} 59.1^{\prime \prime}$ & $92^{\circ} 25^{\prime} 29.6^{\prime \prime}$ & Mudline on building & Good & Zumbro River & Left & ZF10 \\
\hline
\end{tabular}


Appendix 2. Flood-Peak Inundation Maps for Selected Communities, Floods of September 2010, Minnesota 
$93^{\circ} 18^{\prime}$

$93^{\circ} 17^{\prime}$
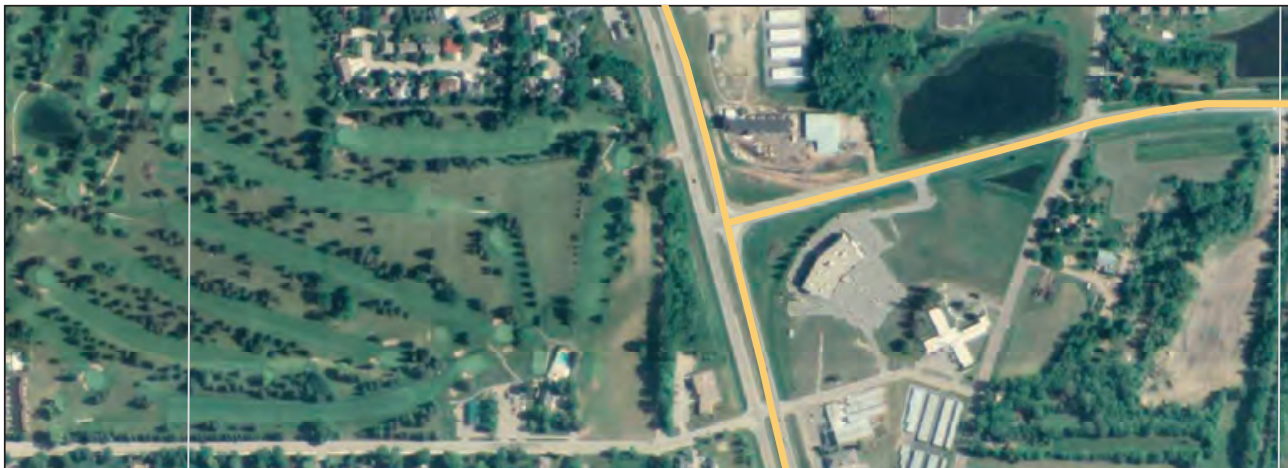

$44^{\circ} 18^{\prime} 30^{\prime \prime}$

$44^{\circ} 18$
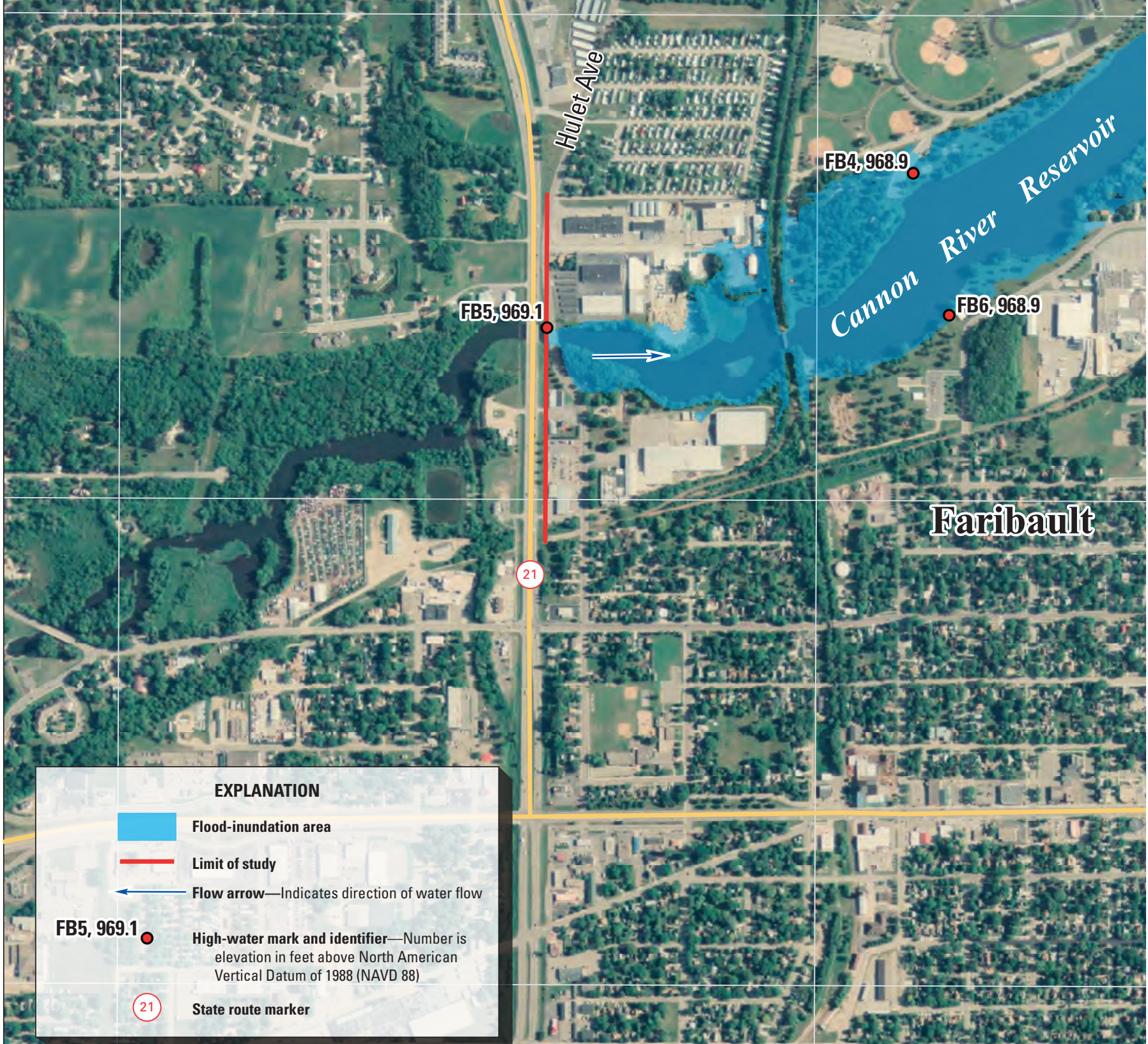

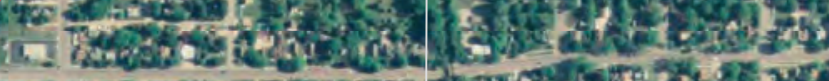
H 3.

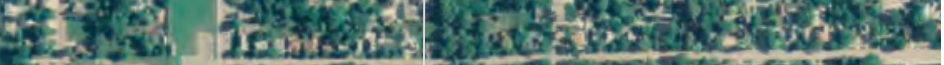

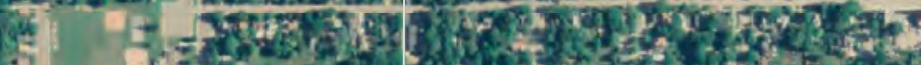

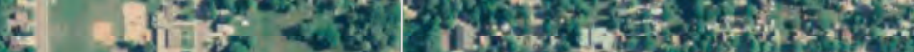

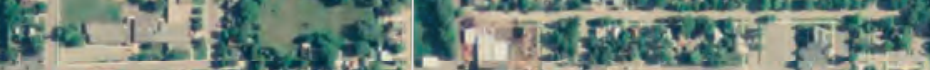

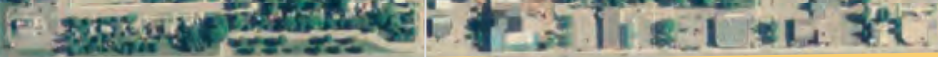

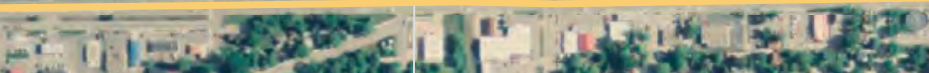
ind 1 5. -5.

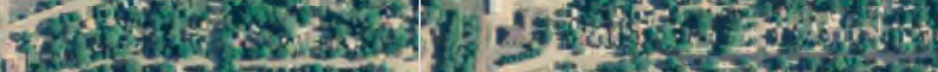

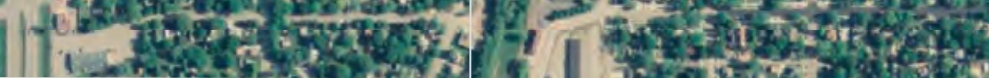

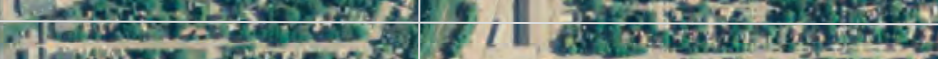
1)

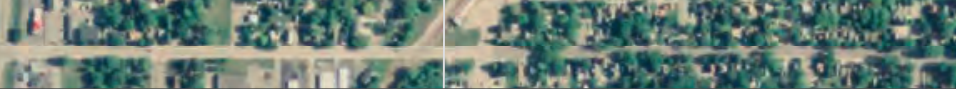

Aerial photograph courtesy of MNGeo, Spatial Data Portal, 2009 National Agriculture Imagery Program, accessed January 2011, at http://www.mngeo.state.mn.us/chouse/metadata/naip09.html.

Figure 2-1. Approximate flood-peak extents and heights, flood of September 2010, for Cannon River and Straight River at Faribault, Minnesota. 
$93^{\circ} 16^{\prime}$

$93^{\circ} 15^{\prime}$

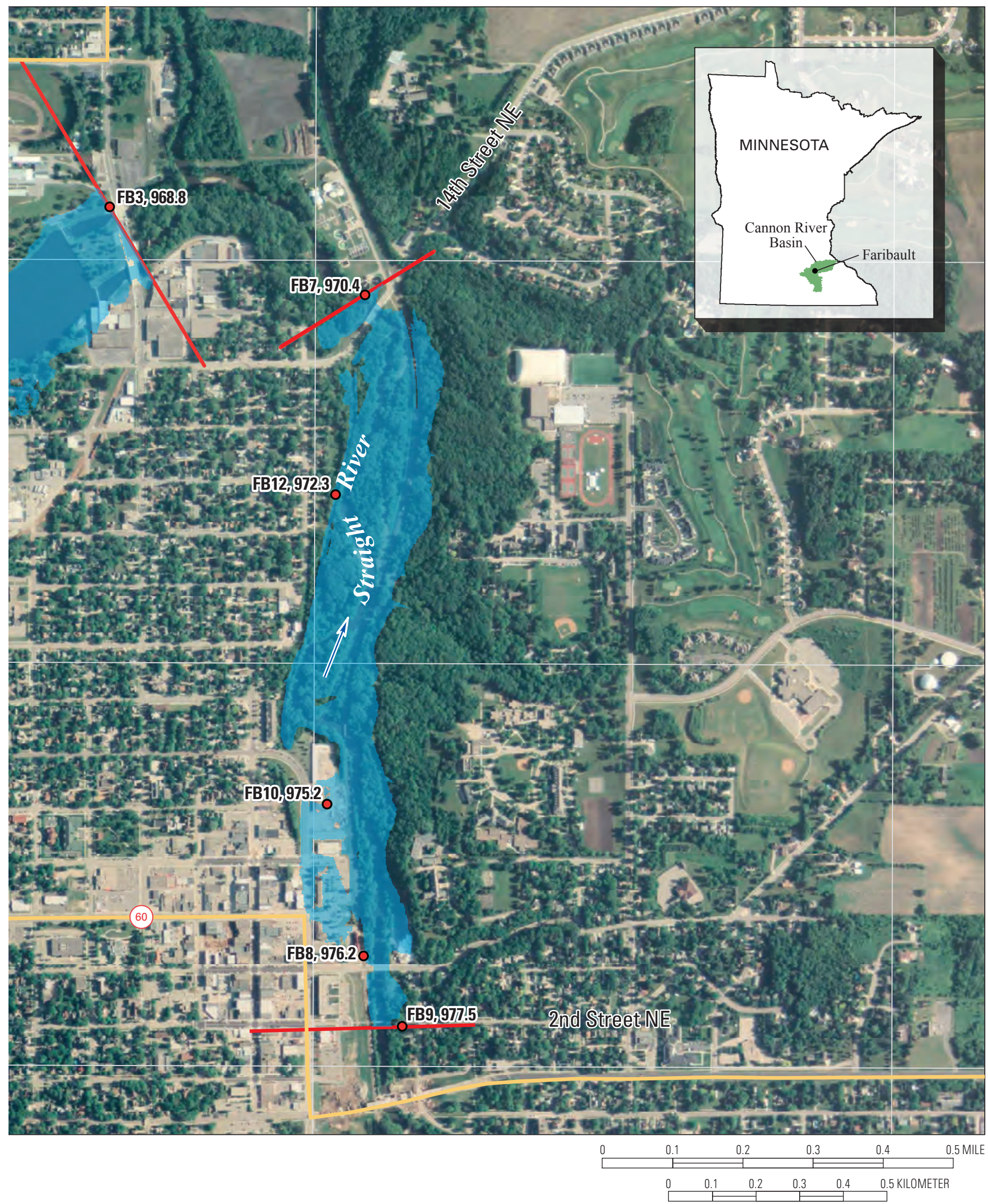




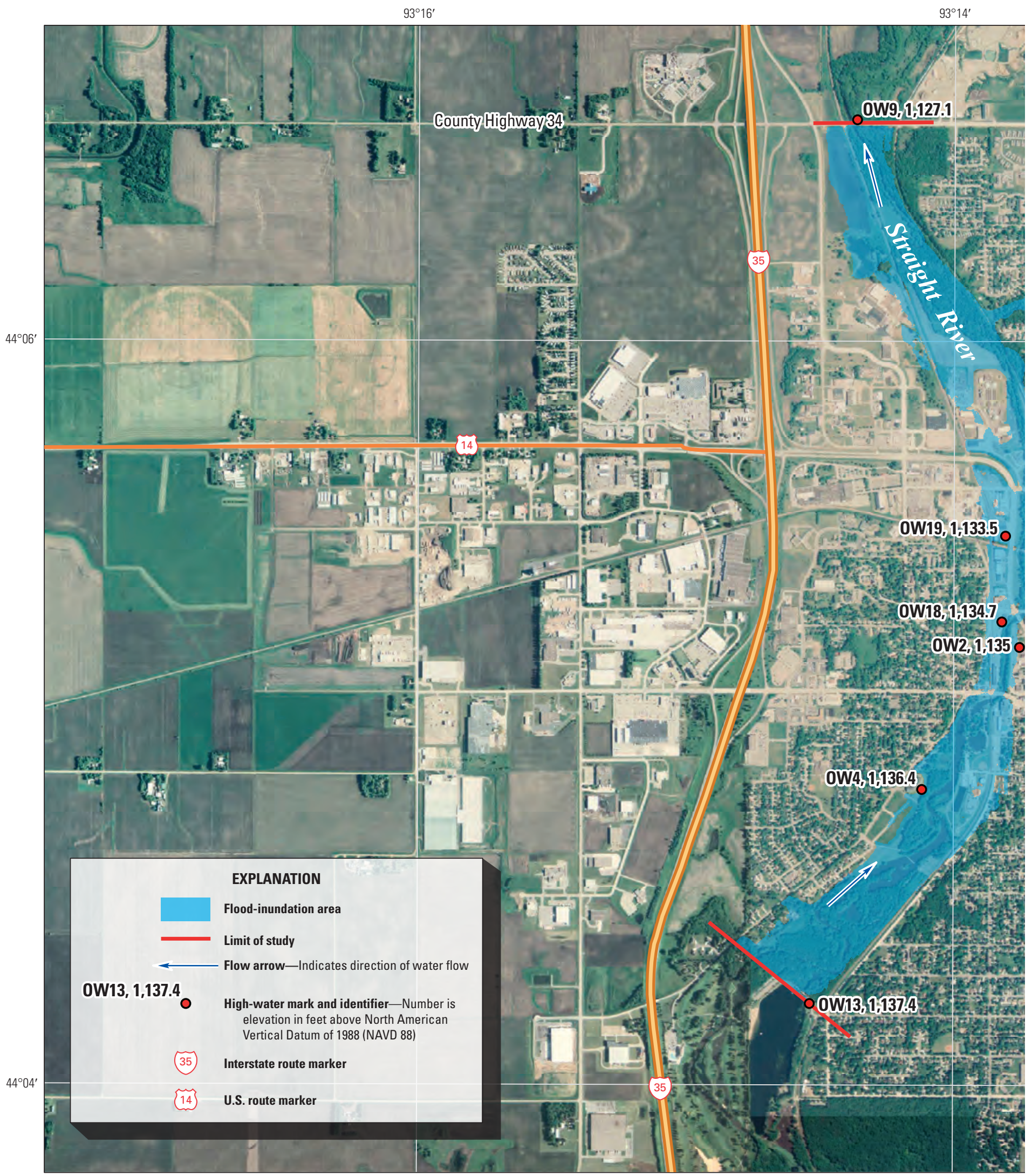

Aerial photograph courtesy of MNGeo, Spatial Data Portal, 2009 National Agriculture Imagery Program, accessed January 2011, at http://www.mngeo.state.mn.us/chouse/metadata/naip09.html.

Figure 2-2. Approximate flood-peak extents and heights, flood of September 2010, for Straight River and Maple Creek at Owatonna, Minnesota. 
$93^{\circ} 12^{\prime}$

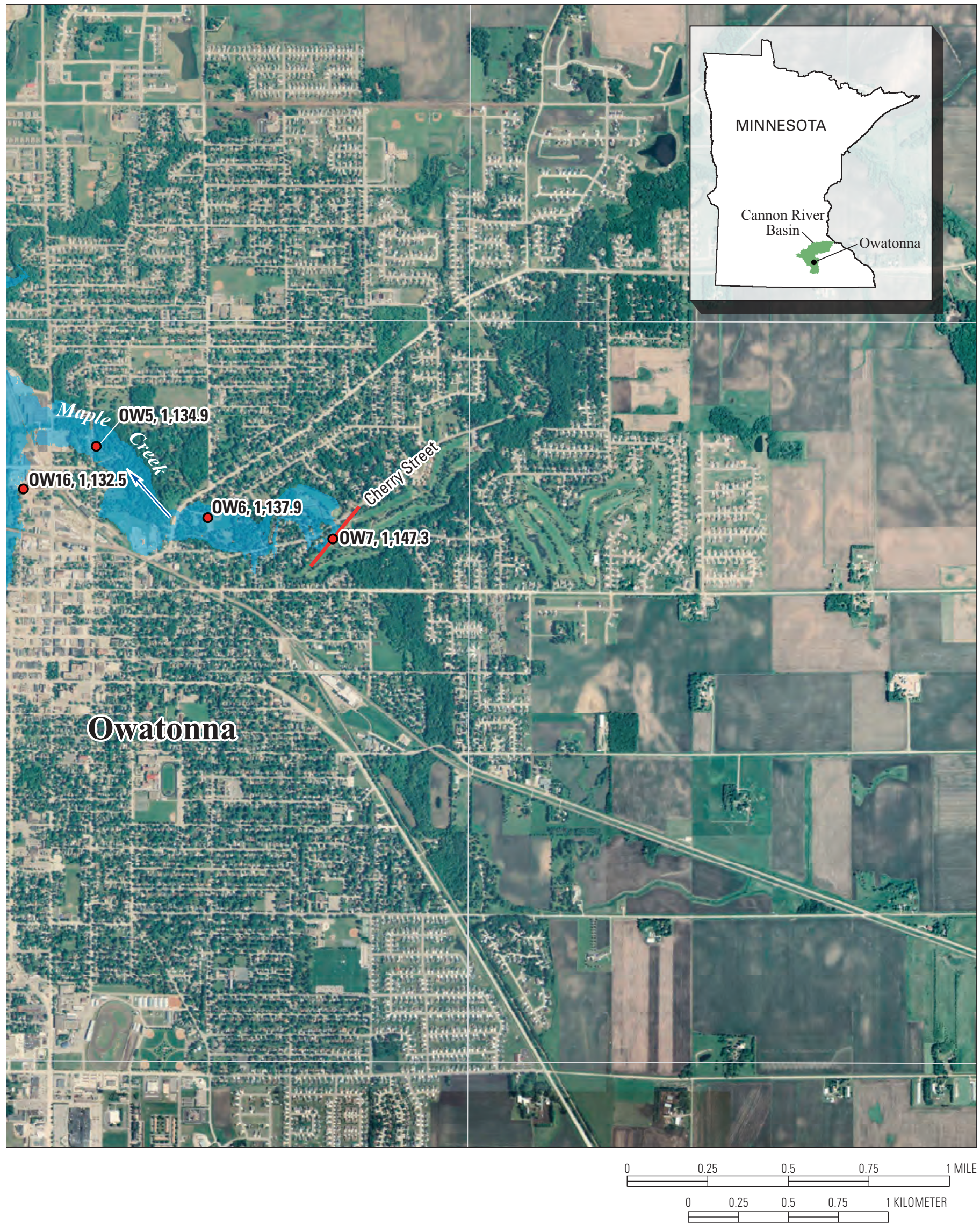




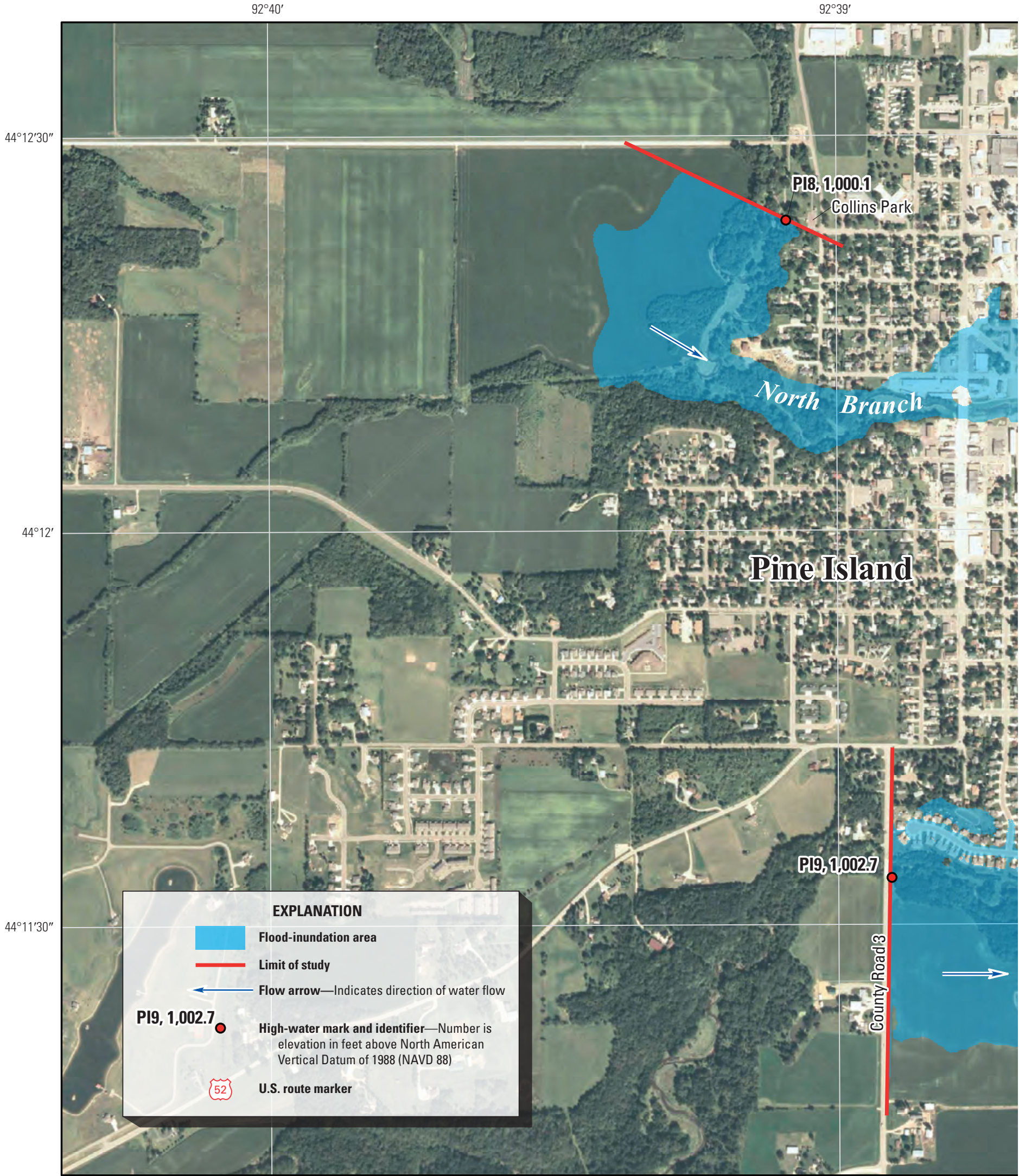

Aerial photograph courtesy of MNGeo, Spatial Data Portal, 2009 National Agriculture Imagery Program, accessed January 2011, at http://www.mngeo.state.mn.us/chouse/metadata/naip09.html.

Figure 2-3. Approximate flood-peak extents and heights, flood of September 2010, North Branch and Middle Fork Zumbro River near Pine Island, Minnesota. 


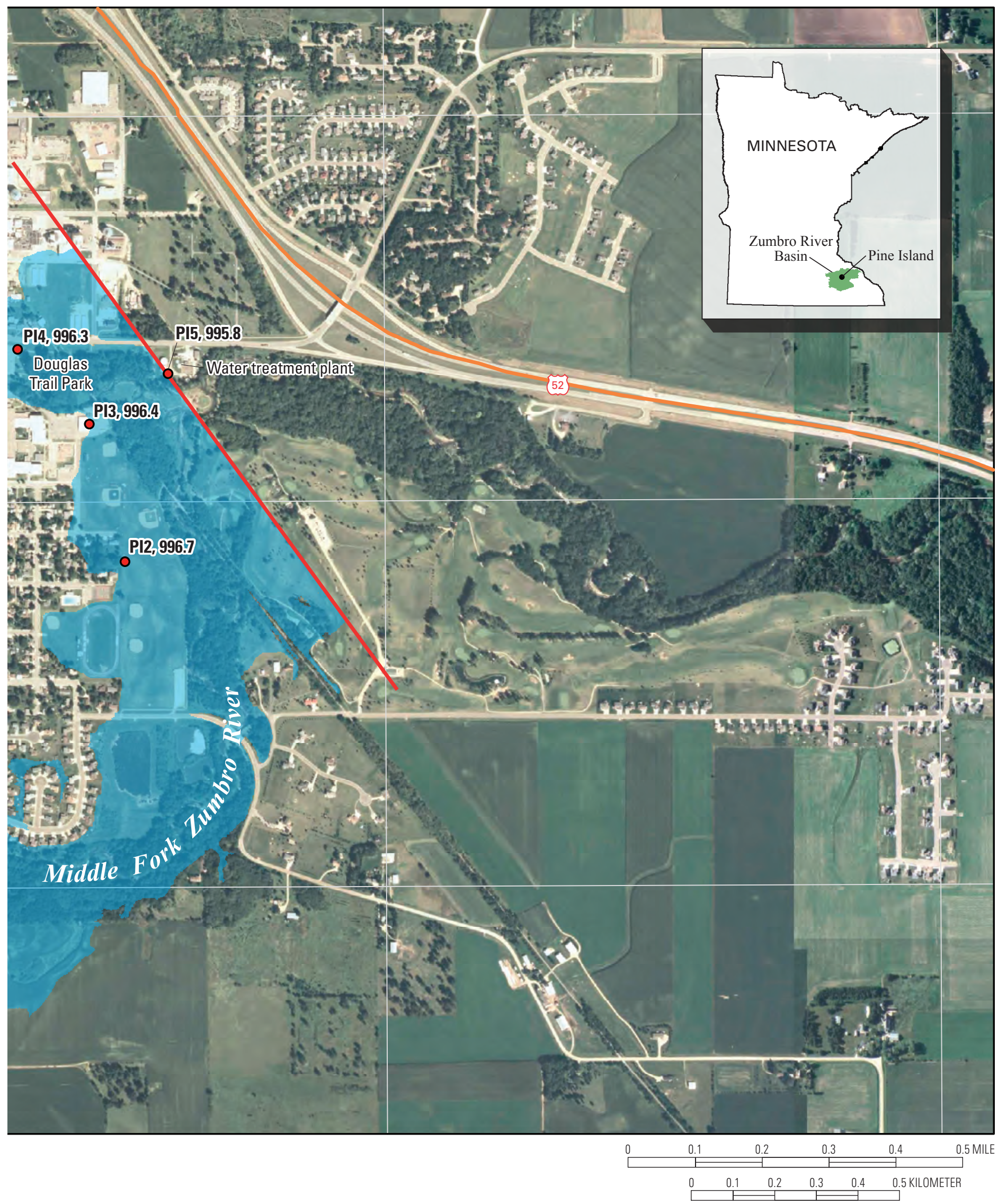




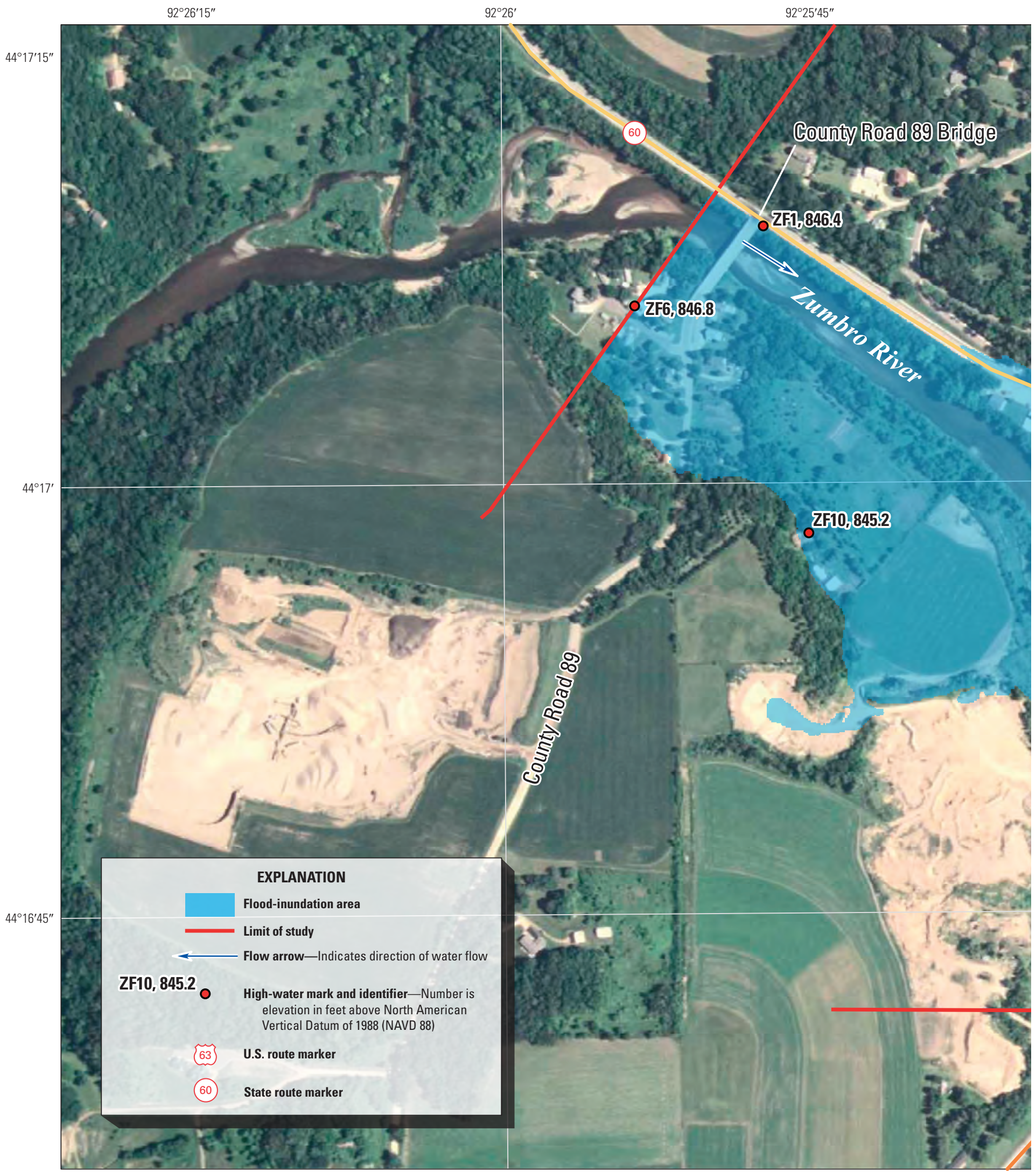

Aerial photograph courtesy of MNGeo, Spatial Data Portal, 2009 National Agriculture Imagery Program, accessed January 2011, at http://www.mngeo.state.mn.us/chouse/metadata/naip09.html.

Figure 2-4. Approximate flood-peak extents and heights, flood of September 2010, for Zumbro River at Zumbro Falls, Minnesota. 
$92^{\circ} 25^{\prime}$

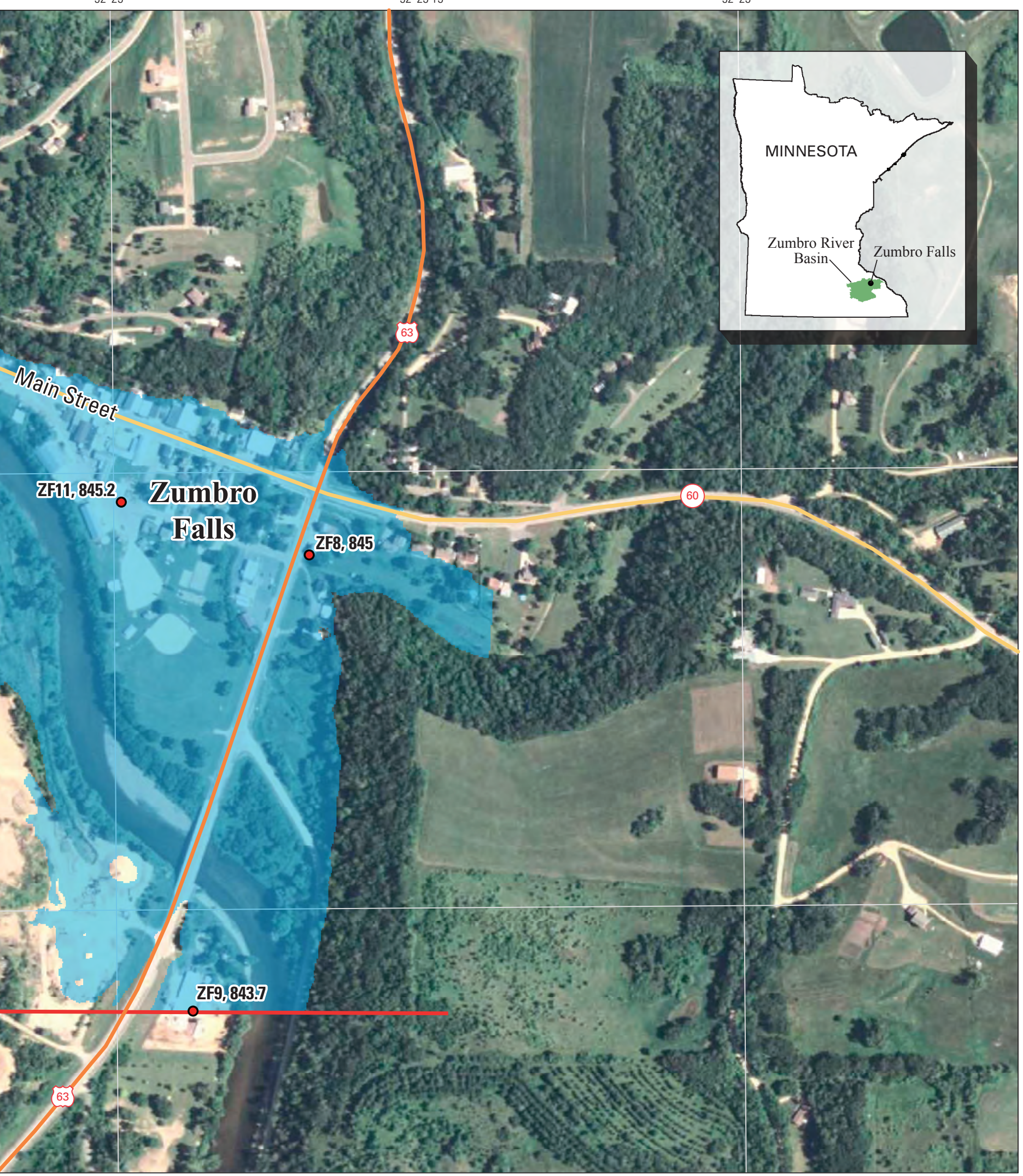




\section{Appendix 3. Flood-Peak Water-Surface Profiles for Selected Sites, Floods of September 2010, Minnesota}

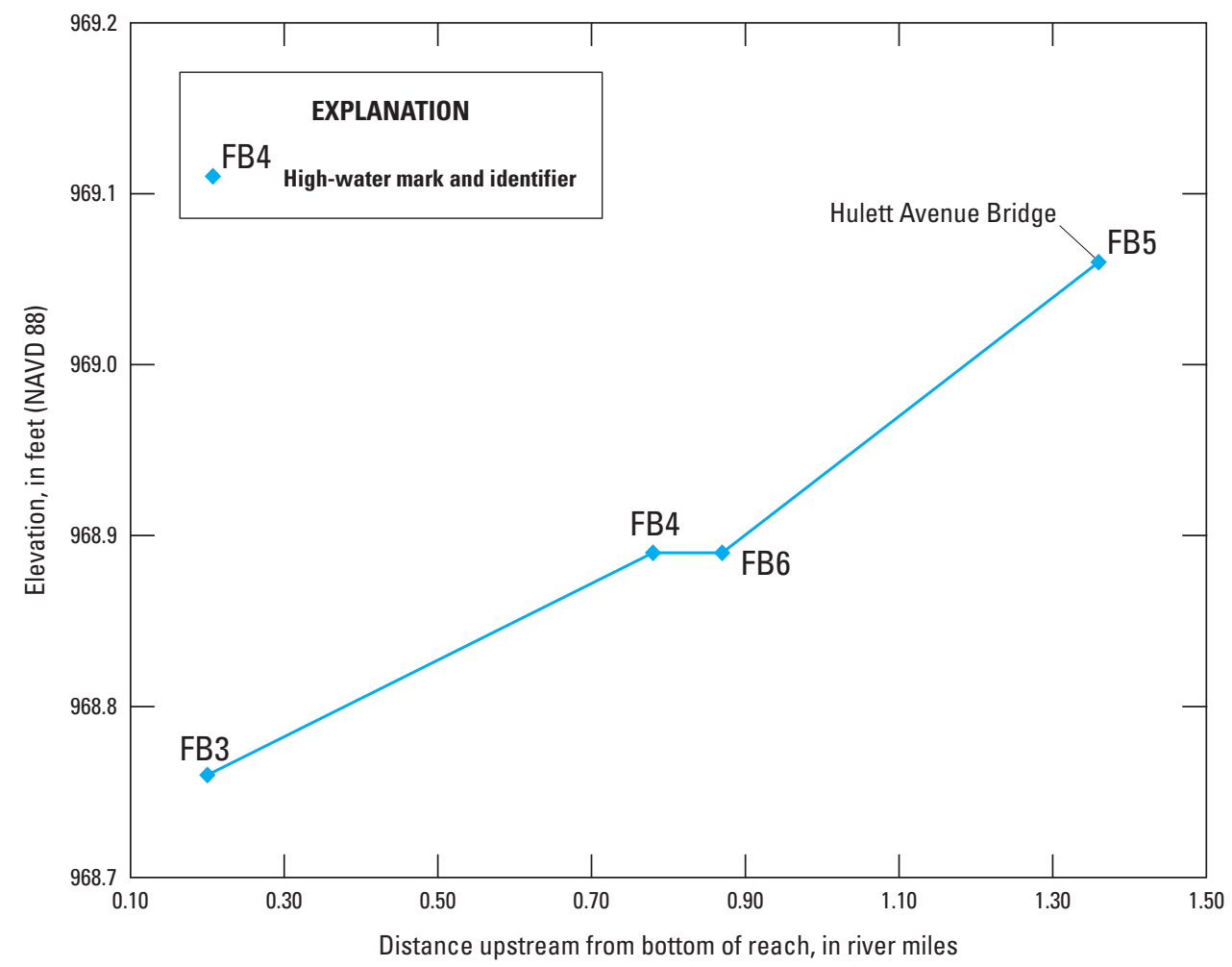

Figure 3-1. Flood-peak water-surface profile with selected high-water marks for the Cannon River at Faribault, Minnesota, for flood of September 2010. Elevation is referenced to North American Vertical Datum of 1988 (NAVD 88). 


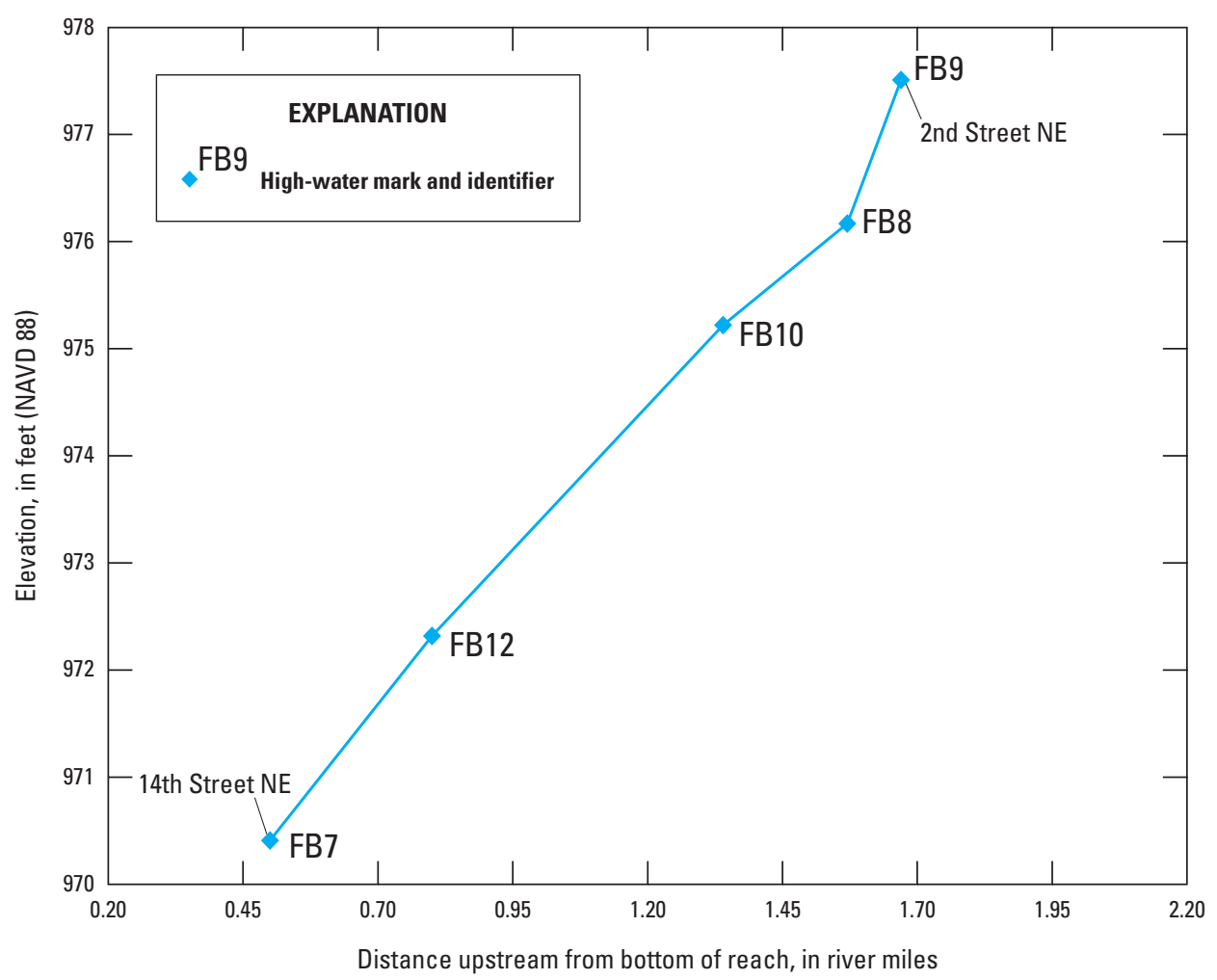

Figure 3-2. Flood-peak water-surface profile with selected high-water marks for the Straight River at Faribault, Minnesota, for flood of September 2010. Elevation is referenced to North American Vertical Datum of 1988 (NAVD 88).

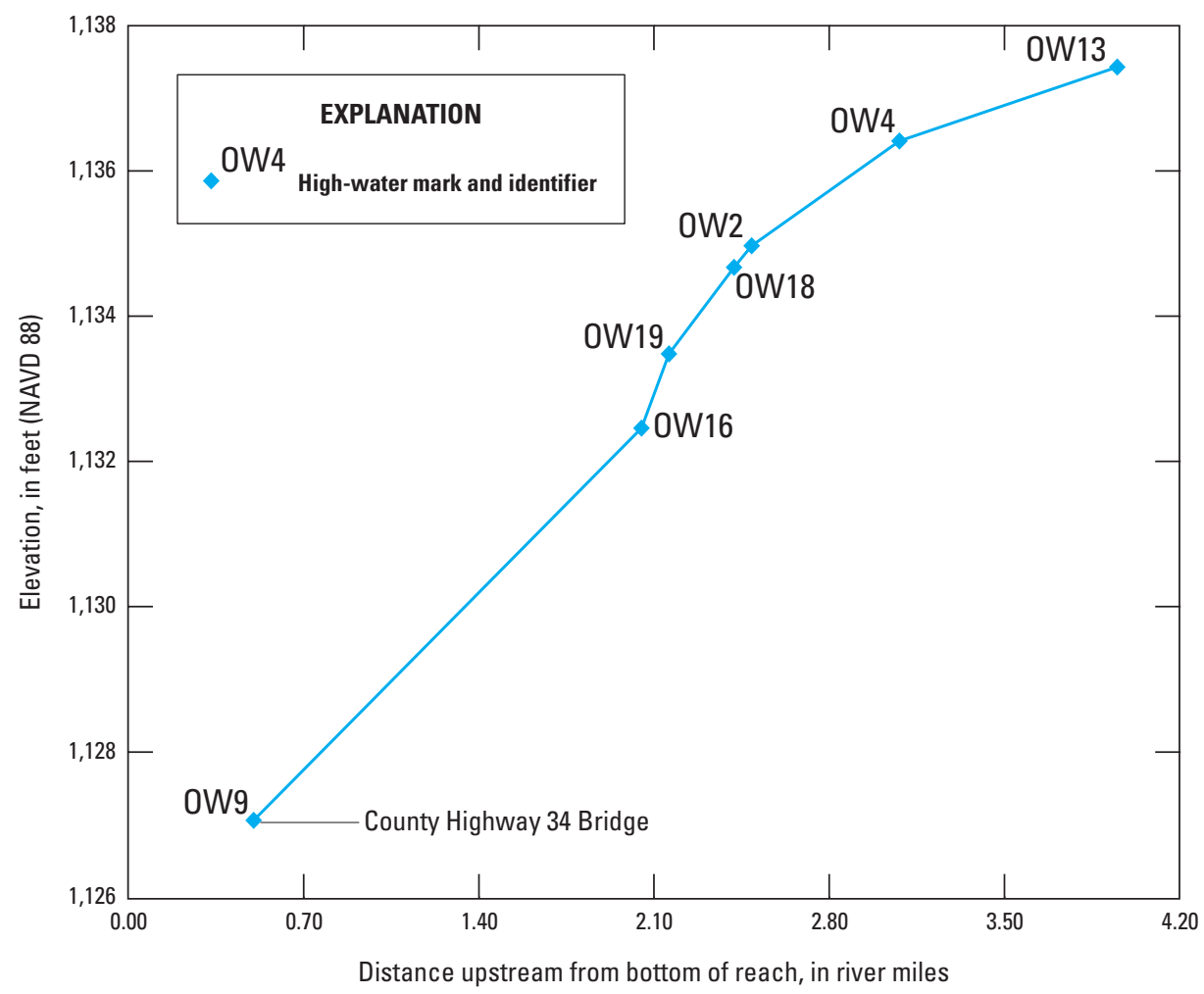

Figure 3-3. Flood-peak water-surface profile with selected high-water marks for Straight River at Owatonna, Minnesota, for flood of September 2010. Elevation is referenced to North American Vertical Datum of 1988 (NAVD 88). 


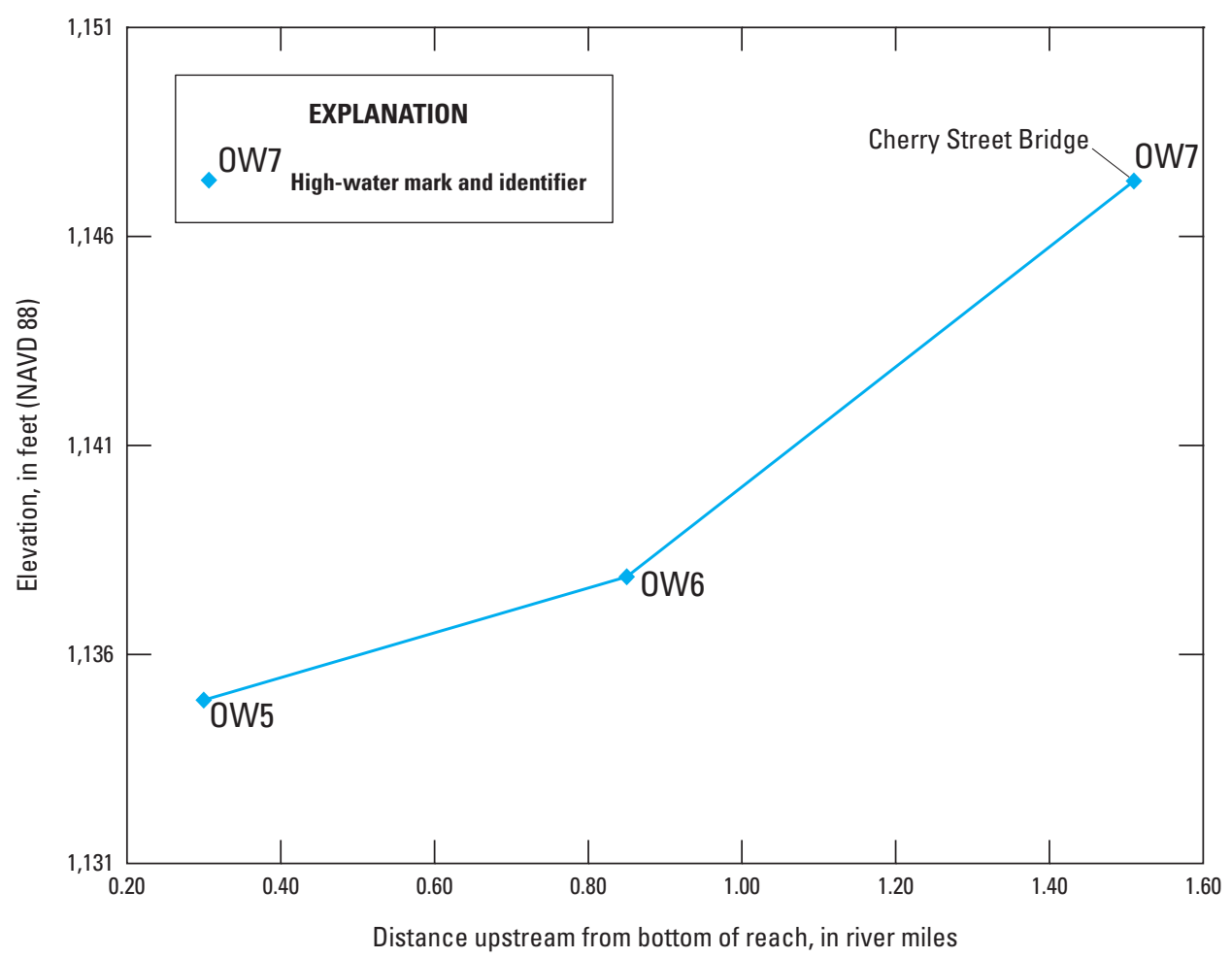

Figure 3-4. Flood-peak water-surface profile with selected high-water marks for Maple Creek at Owatonna, Minnesota, for flood of September 2010. Elevation is referenced to North American Vertical Datum of 1988 (NAVD 88).

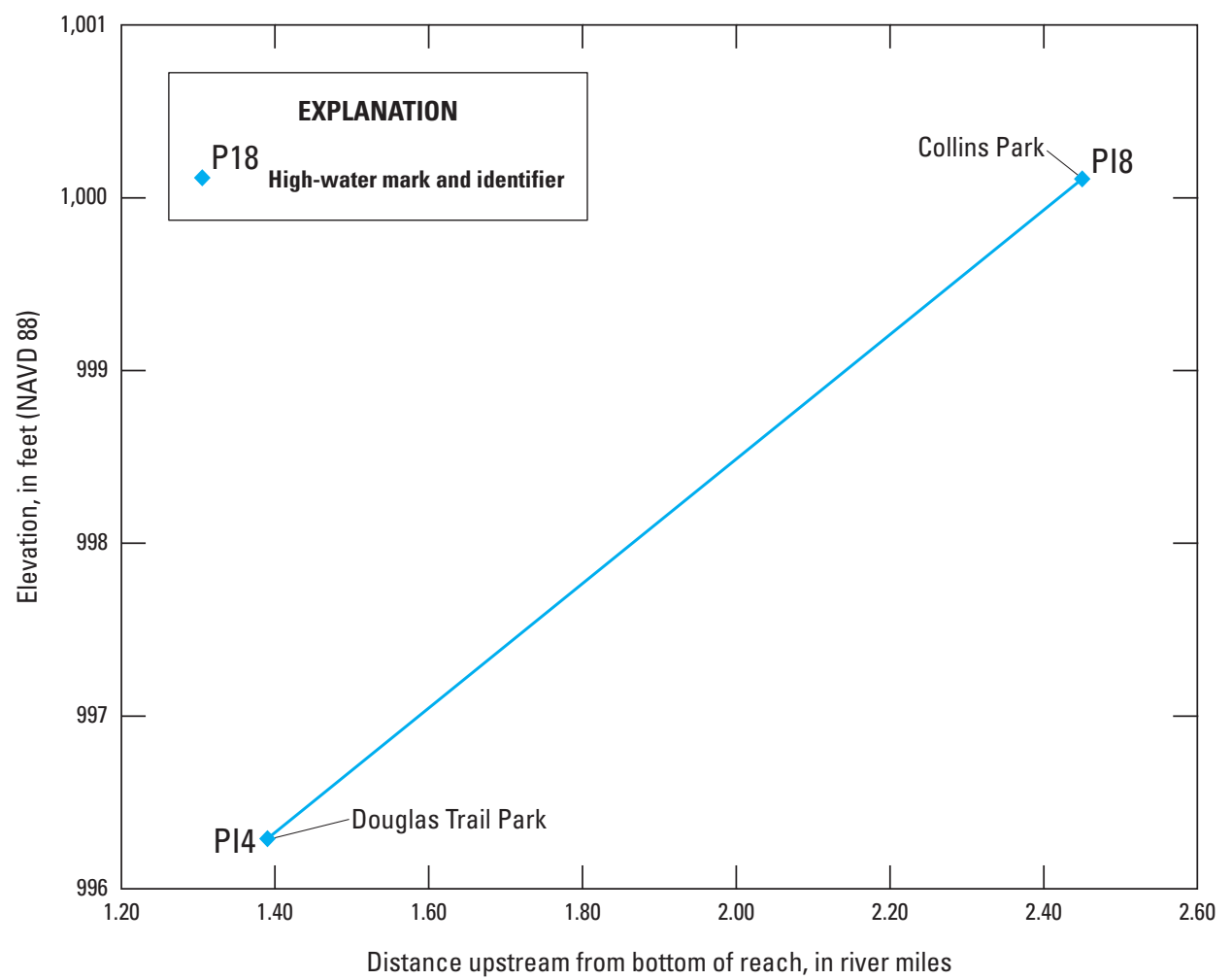

Figure 3-5. Flood-peak water-surface profile with selected high-water marks for the North Branch at Pine Island, Minnesota, for flood of September 2010. Elevation is referenced to the North American Vertical Datum of 1988 (NAVD 88). 


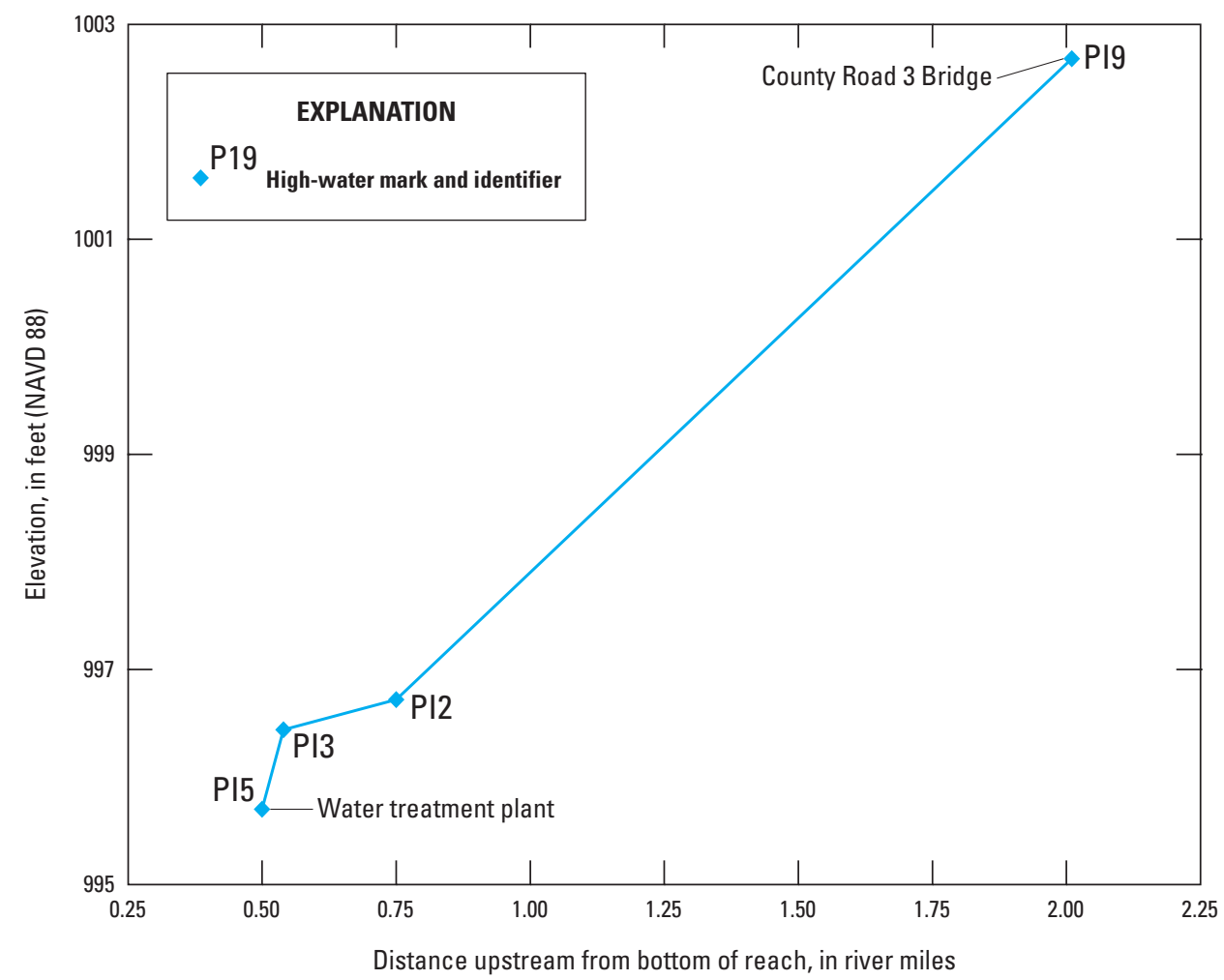

Figure 3-6. Flood-peak water-surface profile with selected high-water marks for the Middle Fork Zumbro River at Pine Island, Minnesota, for flood of September 2010. Elevation is referenced to North American Vertical Datum of 1988 (NAVD 88).

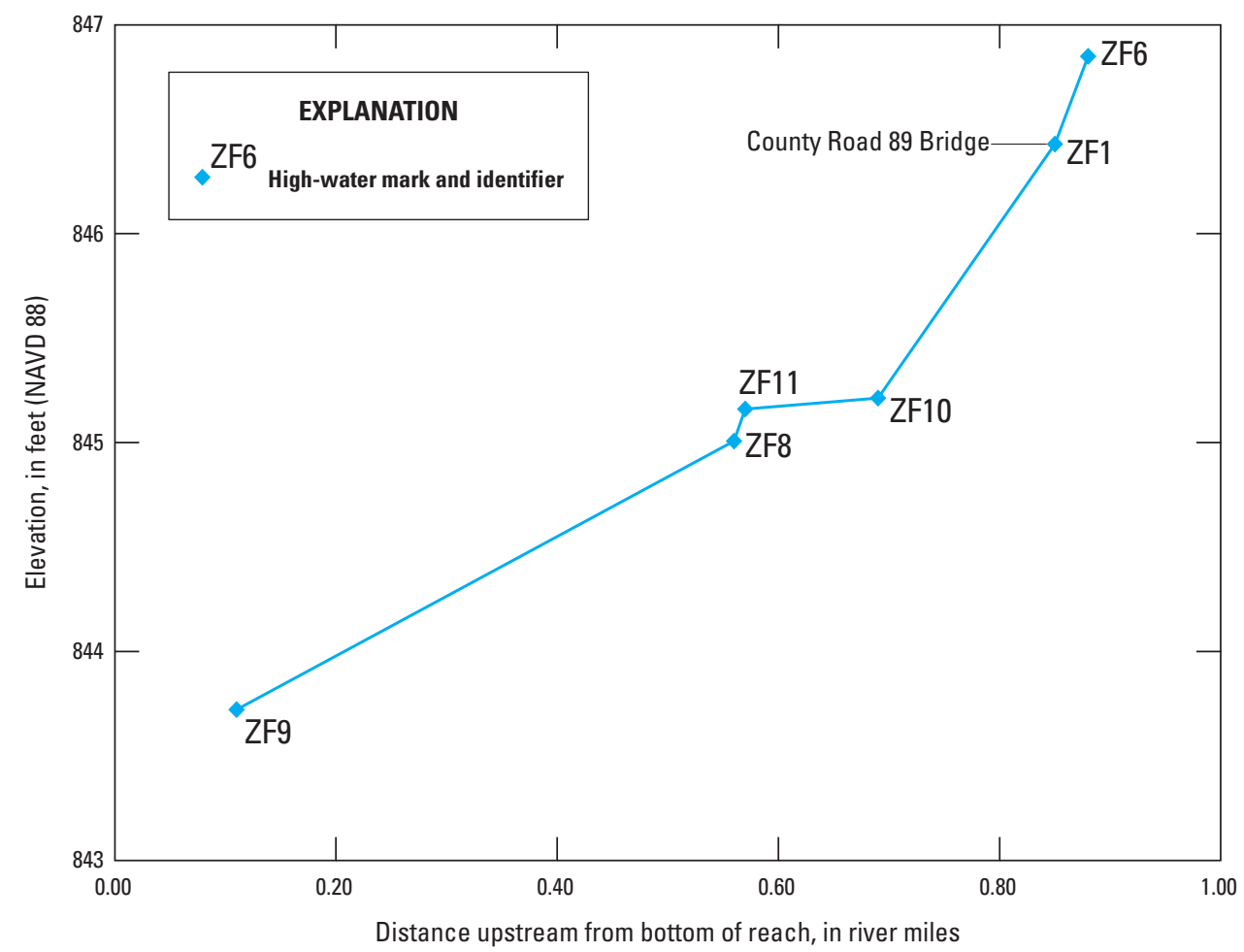

Figure 3-7. Flood-peak water-surface profile with selected high-water marks for the Zumbro River at Zumbro Falls, Minnesota, for flood of September 2010. Elevation is referenced to the North American Vertical Datum of 1988 (NAVD 88). 
Publishing support provided by:

Rolla Publishing Service Center

For more information concerning this publication, contact: Director, USGS Minnesota Water Science Center 2280 Woodale Drive

Mounds View, Minnesota 55112

(763) 783-3100

Or visit the Minnesota Water Science Center Web site at: http://mn.water.usgs.gov/ 

